\title{
Drought impacts on tree phloem : from cell-level responses to ecological significance
}

\section{Salmon, Yann}

2019-02

Salmon , Y , Dietrich , L , Sevanto , S , Hölttä , T , Dannoura , M \& Epron , D 2019 , '

Drought impacts on tree phloem : from cell-level responses to ecological significance ', Tree

Physiology , vol. 39 , no. 2 , pp. 173-191 . https://doi.org/10.1093/treephys/tpy153

http://hdl.handle.net/10138/310815

https://doi.org/10.1093/treephys/tpy153

unspecified

acceptedVersion

Downloaded from Helda, University of Helsinki institutional repository.

This is an electronic reprint of the original article.

This reprint may differ from the original in pagination and typographic detail.

Please cite the original version. 
2

3

4

$5 \quad{ }^{1}$ Institute for Atmospheric and Earth System Research / Physics, Faculty of Science, P.O. Box 68, Gustaf

6 Hällströmin katu 2b, 00014 University of Helsinki, Finland

$7 \quad{ }^{2}$ Institute for Atmospheric and Earth System Research / Forest Sciences, Faculty of Agriculture and

8 Forestry, Latokartanonkaari 7, P.O. Box 27, 00014 University of Helsinki, Finland

$9{ }^{3}$ Department of Environmental Sciences, University of Basel, Schönbeinstrasse 6, CH-4056 Basel,

10 Switzerland

11

${ }^{4}$ Earth and Environmental Sciences Division, Los Alamos National Laboratory, PO. BOX 1663 MA 495, Los Alamos, NM 87545, USA

${ }^{5}$ Kyoto University, Laboratory of Ecosystem Production and Dynamics, Graduate School of Global Environmental Studies, Kyoto 606-8051, Japan

${ }^{6}$ Kyoto University, Laboratory of Forest Utilization, Graduate School of Agriculture, Kyoto 606-8502, Japan

${ }^{7}$ Université de Lorraine, AgroParisTech, INRA, UMR Silva, Faculté des Sciences et Technologies, F-54000 Nancy, France

*corresponding author: yann.salmon@helsinki.fi

Words: 9714 (but with 944 in the box) 


\section{Abstract}

On-going climate change is increasing the risk of drought stress across large areas worldwide. Such drought events decrease ecosystem productivity and have been increasingly linked to tree mortality. Understanding how trees respond to water shortage is key to predicting the future of ecosystem functions. Phloem is at the core of the tree functions, moving resources such as non-structural carbohydrates, nutrients, and defence and information molecules across the whole plant. Phloem function and ability to transport resources is tightly controlled by the balance of carbon and water fluxes within the tree. As such, drought is expected to impact phloem function by decreasing the amount of available water and new photoassimilates. Yet, the effect of drought on the phloem has received surprisingly little attention in the last decades. Here we review existing knowledge on drought impacts on phloem transport from loading and unloading processes at cellular level to possible effects on long distance transport and consequences to ecosystems via ecophysiological feedbacks. We also point to new research frontiers that need to be explored to improve our understanding of phloem function under drought. In particular, we show how phloem transport is affected differently by increasing drought intensity, from no response to a slowdown and explore how severe drought might actually disrupt the phloem transport enough to threaten tree survival. Because transport of resources affects other organisms interacting with the tree, we also review the ecological consequences of phloem response to drought and especially predatory, mutualistic and competitive relations. Finally, as phloem is the main path for carbon from sources to sink, we show how drought can affect biogeochemical cycles through changes in phloem transport. Overall, existing knowledge is consistent with the hypotheses that phloem response to drought matters for understanding tree and ecosystem function. However, future research on a large range of species and ecosystems is urgently needed to gain a comprehensive understanding of the question.

\section{Keywords : allocation, water stress, mortality, long-distance transport, climate change}




\section{Introduction}

On-going global climatic changes will increase the frequency and intensity of drought spells worldwide (Dai 2013) which, in turn, will significantly impact terrestrial vegetation and limit ecosystem net primary productivity (Ciais et al. 2005; Zhao and Running 2010). Trees are long lived species, and their ability to shift their life cycle to avoid drought events like annual plants is limited. Thus, they need to adapt to survive. However, extreme global-change-induced droughts, especially when coupled with increasing temperatures, are believed to overcome tree adaptive abilities thereby inducing vegetation die-offs (Breshears et al. 2005; Allen et al. 2010).

Two main non-mutually exclusive mechanisms for drought-induced mortality have been proposed in the past: carbon starvation and hydraulic failure (McDowell et al. 2008). While evidence for hydraulic failure seems widespread (Anderegg et al. 2015a; Adams et al. 2017), results from experiments and observations are less compelling regarding carbon starvation (Hartmann 2015; Körner 2015; Adams et al. 2017). This is mostly because carbohydrate reserves have been measured in fewer studies than hydraulic failure, and no clear mechanisms for why remaining carbohydrate reserves at plant mortality vary so widely have been identified (Sevanto et al. 2014). Several studies, however, have highlighted the high integration of carbon and water related mechanisms underlying tree responses to drought (O'Brien et al. 2014; Sevanto et al. 2014; Mencuccini et al. 2015; Salmon et al. 2015). Because phloem transport depends on the balance between carbon and water fluxes in plants (see below) it has been proposed as an important determinant of plant susceptibility and responses to drought (Sala et al. 2010; McDowell et al. 2011; Sevanto 2014; Sevanto 2018), even if experimental evidence of phloem failure during drought remains scarce due to the challenges in studying this sensitive, highly reactive tissue (Sevanto et al. 2014; Savage et al. 2016; Dannoura et al. 2019). Therefore, phloem transport was recently identified as a key focus area for better understanding and predicting tree mortality during drought stress (Hartmann et al. 2018).

Besides the destructive impacts of strong and exceptional droughts, milder and non-lethal droughts are also likely to influence plant fitness, shape future plant communities, and alter ecosystem goods and services. Such drought stress is known to affect carbohydrate allocation and transport rate (Ruehr et al. 2009; Barthel et al. 2011) and therefore it inevitably impacts the whole tree and ecosystem carbon balance (Brüggemann et al. 2011). Trees adapted to dry conditions exhibited higher root-to-shoot ratio and deeper root systems (Mokany et al. 2006; Poorter et al. 2012). The transfer of recent photoassimilates belowground and their allocation to root growth and mycorrhiza are therefore tightly coupled to the ability of trees to access limited soil water and nutrients (Lehto and Zwiazek 2011; Brunner et al. 2015). The phloem represents the main pathway from carbon source to carbon sinks in plants and ecosystems, and translocates up to $80 \%$ of assimilated carbon as nonstructural carbohydrates away from the leaves to be used in other plant parts (Lemoine et al. 2013). Phloem also carries nutrients and defensive and signalling compounds within the plant (Van Bel 2003), which are 
involved in tree interactions with their biotic environment. Lowered phloem transport rates under drought would inevitably influence all these processes.

The development of new methods for laboratory experiments such as position emission tomography(PET, Hubeau and Steppe 2015), picogauge tissue pressure measurements (Knoblauch et al. 2014) and magnetic resonance imaging (MRI, Windt et al. 2006) has allowed progress in studying phloem transport in non-woody plants. However, phloem transport, and the interplay between its structure and function still remains poorly understood (Savage et al. 2016) because of the challenges in studying phloem in woody plants and in any plants under field conditions. Because of these experimental limitations, modelling approaches have proven particularly useful (Box 1) to test hypotheses related to phloem response to changes in a tree's environment. However, despite numerous models of phloem transport (Tyree et al. 1974; Minchin et al. 1993; Thompson and Holbrook 2003; Hölttä et al. 2006; Jensen et al. 2011), effects of drought on phloem transport have received attention only in the last few years (Sevanto 2014 and 2018), and only few studies have included the impacts of drought (but see McDowell et al. 2013; and Mencuccini et al. 2015 for recent insights in such attempts). Therefore, a comprehensive understanding of phloem response to drought is still lacking.

Here we review existing knowledge from experimental and modelling studies on trees that investigated (I) the effect of drought on phloem and (II) its consequences for tree function and ecosystem processes. We focus on the current knowledge of how drought (1) limits phloem loading; (2) limits phloem unloading, (3) slows phloem transport and (4) impairs phloem defences. We discuss how a disruption of phloem transport may (5) play a role in tree drought-induced mortality, (6) enhance pest and pathogen damage, and (7) decrease tree ability to maintain symbiotic relation despite the potential cost in terms of fitness. Finally, based on our understanding of phloem role in tree and ecosystem function, we identify research frontiers that require exploration to improve our understanding of phloem response to drought.

\section{Box 1: The basis of phloem function and transport}

It is now widely accepted that phloem transport can be explained by the pressure-flow model, the so-called Münch theory (the origin of which are presented by Knoblauch and Peters 2010; Knoblauch et al. 2016). Briefly, soluble carbohydrates (mainly sucrose) released by sources (mainly the leaf mesophyll and some storage tissues) are loaded into the phloem, thereby increasing the carbohydrate concentration in the sieve element - companion cell complex (SECCC). The resulting increased osmotic pressure (lower osmotic potential) draws water from the nearby xylem and surrounding tissues into the phloem, resulting in an increased turgor pressure in the sieve elements near the source. Near the sink (respiring cells,growing or storage tissue), carbohydrates are unloaded from the phloem to the sink organs. This decreases the osmotic pressure (increases osmotic potential), and water moves from the phloem into other tissues or back into the xylem. Consequently, the turgor pressure in the sieve elements drops near the sink organs. The gradient in 
turgor pressure, from near the source to near the sink, then drives the flow of sap (water and carbohydrates) through the phloem (Figure 1).

The mechanisms of carbohydrate loading in the phloem of leaves has been widely investigated (Gamalei 1991; van Bel and Gamalei 1992; Rennie and Turgeon 2009; Turgeon 2010; Davidson et al. 2011; Liesche 2017) and three main types of loading strategies have been identified: (1) Active apoplastic: sucrose diffuses from the mesophyll into cells in the close vicinity of the SECCC (apoplast of phloem parenchyma cells), where they are actively loaded by selective transporters to the SECCC. This mechanism allows for higher carbohydrate concentrations in the phloem than in the surrounding mesophyll resulting in a lower osmotic potential. (2) Passive symplastic: sucrose moves passively through plasmodesmata within the symplast from the mesophyll to the sieve elements along a concentration gradient, with some possible regulation by the plant, for example through possible changes in plasmodesmata permeability (Liesche 2017). And (3) Polymer trapping: sucrose diffuses from mesophyll cells to intermediary cells, where it is polymerized to raffinose and stachyose. Raffinose and stachyose cannot diffuse back to the mesophyll as they are too big to pass the plasmodesmata, but they can diffuse to the sieve elements through larger plasmodesmata. This creates a one-way flow of carbohydrates to the intermediary cells and increases the carbohydrate (raffinose and stachyose) concentration gradient between the sieve tubes and the mesophyll. This allows for an accumulation of sugar by passive diffusion from the mesophyll into the phloem conduits. The majority of passive loading species are woody species (trees and shrubs, Davidson et al. 2011; Liesche 2017), but not all woody species rely on passive phloem loading.

At the unloading end of phloem transport, two types of mechanisms have been identified in sink organs: (1) symplastic or (2) apoplastic unloading. The mechanisms seem to be sink specific, with, for example, unloading in meristems following a symplastic way, while seeds receive phloem sugars apoplastically (Milne et al. 2018). However, most of the knowledge on phloem unloading is based on crops and information on trees is scarce.

Direct measurements of phloem transport or its driving gradients in turgor pressure have so far mostly been conducted with small seedlings under laboratory conditions (Knoblauch et al. 2016; Savage et al. 2017). Therefore, much of what we understand of phloem transport comes from modelling and indirect measurements such as those of changes in living bark diameter (Mencuccini et al. 2013) or difference in time lags observed at different positions along the stem in respired ${ }^{13} \mathrm{CO}_{2}$ after pulse labelling (Dannoura et al. 2011; Epron et al. 2012; Epron et al. 2016). Modelling and theoretical studies suggest that parameters affecting phloem transport efficiency are phloem and xylem axial hydraulic conductivity, radial hydraulic conductance, and the amount of phloem and xylem tissue (Hölttä et al. 2009). In addition, the elasticity of the phloem sieve tubes plays a role in a dynamic version of a phloem transport model, as it determines the ratio between the change in phloem water content and phloem turgor pressure. Also, local loading and unloading of solutes along transport phloem (Figure 1, also known as "leaky phloem") could compensate 
for short term changes in either source and sink activity or water status (Liesche and Schulz 2018). In fact, phloem sieve tubes have been found to be leaky at least in some species (Minchin et al. 1983; Minchin and Thorpe 1987; De Schepper et al. 2013; Epron et al. 2016). However, a leaky phloem and the dynamics of solute unloading and reloading has rarely been incorporated into models (for two notable exceptions, see the work of Cabrita et al. 2013; Minchin and Lacointe 2017). Due to the length of the phloem transport pathway in trees, it has been asked whether the simple pressure flow mechanism could be sufficient to insure efficient phloem flow (Ryan and Asao 2014) because only a limited turgor pressure difference can be built up between the source and sink ends of the phloem before the concentration of sugars that would be needed near the source would increase viscosity to a point where phloem transport would be impaired. Recent evidence however suggests that anatomical adaptations, even in gymnosperms, are sufficient to explain phloem transport in the Münch framework (Savage et al. 2017; Liesche and Schulz 2018).

Modelling phloem flow itself is not very challenging as it obeys the laws of physics. However, setting realistic values for phloem loading and unloading and the different parameters needed for such models is a major challenge (Minchin and Lacointe 2017) given the lack of experimental data. Furthermore, how much these parameters can vary spatially, temporally and among species is also unknown.

\section{How does drought affect phloem function in trees?}

Potentially, drought impacts on all tree processes requiring energy (i.e., carbohydrates) and their interactions (Figure 2) are integrated in phloem function. Little is known about how drought influences the biochemical processes of loading and unloading in trees. Nonetheless, existing knowledge about carbohydrate concentration dynamics in source and sink tissues allows to draw some conclusion about the likely effects of drought on phloem function. Here we review existing knowledge about the main processes affecting phloem function during drought: loading, unloading, transport and defences (Table 1 and Table 2).

\section{Does drought impair phloem loading through changes in source activities?}

There are several reasons why during drought carbohydrates may become less available to be transported from leaves to other parts of the plant slowing down phloem loading and transport (Figure 2). Generally, trees close stomata in response to drought in order to limit water loss through transpiration. Consequently, photosynthesis is also impaired by drought leading to a decrease in the amount of carbon assimilated and thus potentially available for export to the phloem (McDowell 2011). Nevertheless, although this has not yet been documented, differences between species located at the opposite ends of the isohydric-anisohydric continuum can be expected. In the more anisohydric trees, leaf growth is more sensitive to drought than photosynthesis (Hsiao et al. 1976; Hummel et al. 2010). Therefore, one may expect that in the absence of other leaf-level carbon sinks more carbohydrates may be available for export under mild drought conditions resulting in only small or no effect on phloem loading. While leaf respiration often decreases during drought, maintenance respiration is less sensitive to drought than photosynthesis and the ratio of photosynthesis to leaf respiration is thought to 
decrease (Flexas et al. 2006; Atkin and Macherel 2009). This could potentially reduce the amount of carbohydrates available for export and should therefore also affect phloem loading rate (Figure 2). Which one of these occurs first and influences loading rates most depends on the plant species and severity of drought. Accumulation of soluble organic compounds for osmotic adjustment in leaves is considered the main process that competes with phloem loading by reducing the amount of carbohydrates available for export (van Bel and Gamalei 1992). Accumulation of hexoses at the expense of sucrose was observed in oak leaves under drought (Epron and Dreyer 1996), while more specific soluble organic compounds (e.g. cyclitols) may accumulate in other species such as pine or eucalypts (Nguyen and Lamant 1988; Arndt et al. 2008).

Drought may also change the partitioning of available carbohydrates within the leaf and increase production of defensive or protective compounds (Figure 2). The fraction of photosynthetic carbon lost as isoprene has been found to increase with drought (Figure 2) in several isoprene emitting tree species (Pegoraro et al. 2004; Brilli et al. 2007). Isoprene emission protects leaves against elevated temperature (Sharkey et al. 2008), which often occurs under drought because stomatal closure limits the evaporative cooling of foliage. Drought also promotes the accumulation of secondary metabolites such as condensed tannins in foliage (McKiernan et al. 2016) thereby immobilizing some carbon in the leaf (Figure 2). Maintaining or enhancing the content of secondary metabolites may be needed to protect leaves against other drought-related abiotic stresses such as photoinhibition and high temperature, and biotic stresses such as attacks by pathogens and herbivores (Niinemets 2016, see below). However, both isoprene emission and synthesis of secondary metabolites may potentially decrease under severe drought with a decrease in available carbohydrates.

The need for osmotic adjustment and synthesis of secondary metabolites could explain all or part of the observed increase in ${ }^{13} \mathrm{CO}_{2}$ or ${ }^{14} \mathrm{CO}_{2}$ label residence times in leaves under drought (Ruehr et al. 2009; Blessing et al. 2015; Dannoura et al. 2019) (See also Table 1). While there is a clear need to better address how water stress of different intensities and different durations alters carbon partitioning within the leaf between growth, export, osmoregulation and defence (Desalme et al. 2017), existing knowledge strongly suggests that the decrease in assimilation, increase in respiration over photosynthesis ratio, and upregulation of metabolic pathways that result in the formation of volatile compounds, osmotic solutes, and secondary metabolites decreases the fraction of assimilates available to be loaded in the phloem (Figure 2).

Evidence from non-woody species suggests that the net effect of the competition among these different carbon sinks in the leaves that challenges phloem loading might differ between plant species and particularly between phloem loading strategies. While apoplastic loaders may have sucrose concentrations in the sieve tubes up to several orders of magnitude above those in the mesophyll cells (Ainsworth and Bush 2011), the passive symplastic pathway requires that the concentration of sucrose is higher in the mesophyll cells than in the sieve tube for diffusion through plasmodesmata to occur (Rennie and Turgeon 2009)(Box 1). In several apoplastic, i.e. actively loading species, genes of sucrose transporters are upregulated under drought (Xu et al. 2018). In Arabidopsis, an active loader, it was further shown that these genes were upregulated both in shoots 
and roots, which was thought to account for an enhanced carbon export rate to the roots (Durand et al. 2016). Less data are available and thus less is known about the regulation of phloem export in passive symplastically loading species, which are mainly tree species (van Bel and Gamalei 1992; Davidson et al. 2011). Sucrose transporters in the tonoplast of mesophyll cells control the exchange of sucrose between the vacuole and the cytoplasm in passive symplastically loading species (Liesche 2017). Gene expression of one of these transporters was downregulated under water stress in poplar (Frost et al. 2012; Xu et al. 2018), which should lead to increased sugar sequestration in the vacuole and less carbon export from leaves (Payyavula et al. 2011). Therefore, the proposition that the apoplastic pathway for phloem loading may be an adaptive response to drought and low temperature is appealing (van Bel and Gamalei 1992). So far, however, little data are available regarding loading strategies in trees from different habitats with contrasting environmental conditions and the probably indirect correlation between loading types and climate is weak and still poorly understood (Van Bel 1992; Davidson et al. 2011).

\section{Does drought affects phloem unloading through changes in sink activities?}

Drought effects on sink activities and phloem unloading are far less studied and understood than on source activities and phloem loading. Plants grown under mild drought generally exhibit higher root-to-shoot biomass ratios than plants grown under well-watered conditions, either from greater partitioning of photosynthesic product towards root growth in agreement with the optimal partitioning theory (Bloom et al. 1985) or from difference in tissues turnover time, or both. This results from a more pronounced reduction in aboveground growth than in root growth (Löf et al. 2005; Hummel et al. 2010). However, these changes in allocation are likely species specific and a function of the tree development stage, as no such effect was observed in a mature beech forest (Meier and Leuschner 2010). Sugar unloading in elongating root tips of Arabidopsis follows a symplastic route (Oparka et al. 1994). Therefore, turgor maintenance in expanding root cells and changes in cell wall extensibility (Frensch and Hsiao 1995; Hsiao and Xu 2000) may play a role in sustaining carbon transfer belowground under mild stress until root elongation stops (Figure 2). Using pulse labelling, an increased belowground allocation of recent photosynthates has indeed been observed in young beech saplings under mild drought (Hommel et al. 2016). Thus, despite some variability, existing evidences suggest the possibility of an increase in phloem unloading under mild drought in root tissues. Root exudation has also been found to increase under drought (Figure 2), at least under moderate water stress (Reid and Mexal 1977).

Growth is usually one of the first processes to be downregulated (McDowell 2011, and references therein) or impaired due to higher sensitivity to lower water potential, although trees growing in some very competitive ecosystems might maintain growth even under intense drought (Rowland et al. 2015). Thus, under severe drought, the growth of potential sink tissues ceases also suggesting a cessation of phloem unloading in these tissues (Figure 2), but the results are somewhat ambivalent. Some studies have observed decreasing nonstructural carbohydrate pools belowground with drought (Hartmann et al. 2013b) suggesting decrease in phloem transport and unloading of new resources. While other studies support the idea of active carbohydrate storage (see Wiley and Helliker 2012 for more details on the topic) under drought (Hagedorn et al. 2016) 
suggesting that phloem transport and unloading is not impaired and active storage might even help maintain phloem transport by maintaining the osmotic and turgor gradient across the phloem (see Box 1). The carbohydrate dynamics in sink tissues are necessarily associated with phloem response to drought by (1) the changes it creates in the driving forces of phloem flow (Box 1), and (2) as a result of phloem transport between sources and sinks. However, the lack of empirical data on sink responses to drought does not allow making strong conclusions about phloem unloading responses to severe drought (Figure 2). Consequently, there is an urgent need to investigate phloem unloading and sink responses to drought across a range of species and plant functional groups, and a separation of drought effects on biochemistry, carbon availability and tissue growth, particularly under drought severe enough to strongly limit the carbon sink. Although this kind of studyremain a challenge in trees, isotope labelling experiments may be designed to specifically address the drought-induced modulation of the unloading rate of carbohydrates in different types of sink tissue for either supporting growth (fine root elongation, expanding leaves and twigs, secondary growth of stems or perennial branches and roots) or for being stored in parenchyma (stems, buds). Similar experiments could also be used to understand how sink strength and priority among sinks are adjusted under low photoassimilate production in source leaves during drought.

\section{How does drought affect phloem transport?}

Phloem transport velocity has been found to decrease during drought (Ruehr et al. 2009; Dannoura et al. 2019, see also Table 1 and Figure 2). From a theoretical point of view this can be expected to occur due to at least three non-mutually exclusive reasons: (1) changes in growth and anatomy of the phloem which constrains phloem conductivity, (2) changes in balances between phloem loading and unloading which can alter the turgor gradient driving phloem flow (see Box 1) and finally (3) dynamic changes in phloem properties.

(1) How do drought-induced changes in phloem growth and anatomy affect phloem transport?

The effect of drought on phloem anatomy mostly depends on the timing and length of the drought. Trees facing short-term drought or drought not concurring with secondary growth experience only little effect of drought on phloem anatomy, except a potential legacy effect in subsequent growing seasons due to decreased resource availability. Such an effect on sieve element diameter may last several years owing to the legacy effect of previous years' photosynthesis and stored carbohydrates on cambial growth (Berninger et al. 2004; Skomarkova et al. 2006). However, if trees are affected by longer droughts concurrent with phloem growth, phloem anatomy is likely to be significantly impacted (Table 1). While less is known about the regulatory factors (e.g. hormones, transcription factors) involved in the development of the phloem cell compared to xylem cells (Nieminen et al. 2012; Schuetz et al. 2013), phloem formation has long been thought to exhibit a lower sensitivity to water supply conditions than xylem formation (Gričar and Čufar 2008; Gričar et al. 2009; Prislan et al. 2013; Swidrak et al. 2014). However, recent evidence suggests that beyond a certain level of drought stress, phloem formation is also affected by water shortage (Figure 2). Water availability can affect phloem growth since turgor is the driving force for cell expansion in plants (Lockhart 1965; Hölttä et al. 
2010). Under drought, low water potentials reduce cell turgor and impair cell enlargement unless osmotic adjustment or cell wall loosening compensate for the decrease in turgor (Hsiao 1973; Cosgrove 1993; Kozlowski and Pallardy 2002; Schopfer 2006). Osmotic adjustment (Figure 2), is known to sustain root growth and water extraction under mild drought (Frensch and Hsiao 1995), and has been reported in the phloem of crop plants under drought (Girousse et al. 1996) but to the best of our knowledge has rarely been documented in trees (Xiloyannis et al. 1999). Modelling studies suggest that xylem water potential influences turgor pressure in sieve elements (Hölttä et al. 2006; De Schepper and Steppe 2010), and thus, a decrease in water potential under drought is expected to decrease phloem turgor pressure (Mencuccini et al. 2013; Sevanto et al. 2014) leading to a reduction in the expansion of immature sieve cells originating from the division of cambial cells (Figure 2). A decrease in phloem loading when stomata close and $\mathrm{CO}_{2}$ assimilation is reduced also contributes to the inability of plants to maintain phloem cell turgor and cambial growth under drought. In addition to turgor, accumulation of abscisic acid (ABA) is known to suppress cambial growth in trees under drought (Sorce et al. 2013).

Indeed, the size of phloem cells, including sieve cells, in spruce was shown to be site-specific and positively influenced by the amount of precipitation (Gričar et al. 2015). Sieve element diameter was also lower in young beech trees growing under prolonged drought (Dannoura et al. 2019). Such a reduction in sieve element diameter may have a large impact on phloem transport because in Hagen-Poiseuille flow, hydraulic conductivity depends on the fourth power of tube radius. Small sieve cells in tall Douglas-fir trees that were related to a height reduction in shoot midday water potential were the main factor accounting for low phloem conductivity in tall compared to small trees (Woodruff 2014). Interestingly, an increase in phloem conduit diameter under drought in piñon pine, and no change in one-seed juniper with ambient and $50 \%$ precipitation removal was found (Sevanto et al. 2018), suggesting that species adapted to drought may be affected less or differently than species from moist environments. However, we lack experimental data showing whether water in the phloem comes directly from the xylem or through the phloem parenchyma cells and therefore cannot directly asses the influence of declining xylem water potential on phloem growth.

The overall ability of the phloem to transport carbon does not only depend on the diameter of sieve elements and their individual hydraulic conductance but also on the conductance of the whole tissue. The phloem total conductance is a function of the total number of active sieve elements, and thus of the total area of the conductive phloem and sieve element density, the number of sieve elements per unit area (Epron et al. 2019). The thickness of the active phloem depends on the production rate of cell initials and the duration of cambial cell production. Precipitation can positively affect the latter and thus the width of annual phloem increment (Gričar et al. 2014). The thickness of the active phloem of young beech trees has been shown to be negatively affected by prolonged drought (Dannoura et al. 2019). However, the total amount of sieve tubes was not affected resulting in a higher sieve tube density in trees under drought. This higher sieve element density is consistent with the lower sieve tube diameter mentioned above: the smaller the conduits, the more can be packed into a given cross-sectional area of conductive phloem (Jyske and Hölttä 2015). The influence 
of this more dense packing of smaller conduits on phloem transport capacity depends on the ratio of conduit diameter vs. number of conduits, and how hydraulically independent the conduits are, which will likely depend strongly on phloem anatomy of the species in question (Sevanto 2018). In the extreme case of completely independent conduits, the total transport capacity would be a sum of the conductivity of all conduits and proportional to the fourth power of the conduit radii (Hagen-Poiseuille law). In the case of high hydraulic coupling between adjacent conduits, the small conduit radius influences the conductive capacity less than to the fourth power, and the drought-induced anatomical changes in the phloem might have only a slight effect on total transport capacity (Sevanto 2014). To shed light on the influence of anatomical changes on phloem transport under drought, experiments evaluating the water and carbohydrate exchange capacity and flow rates between phloem conduits in the transport phloem are needed (Sevanto et al. 2011; Stanfield et al. 2017).

(2) How do drought-induced changes in source-sink balances affect phloem transport?

When drought becomes more intense, carbohydrate transport in the phloem can be expected to decrease as typically both the source (photosynthesis) and at least part of the sink (growth and respiration) activity rates decrease (Blessing et al. 2016; Hagedorn et al. 2016). Since photosynthesis can be maintained when drought is intense enough for growth to stop (Pantin et al. 2013; Klein et al. 2014), a sink-limited slowdown of transport under drought is likely to occur (Lemoine et al. 2013). A slower export of new photoassimilates can feed back to stomatal regulation of photosynthesis via increased concentrations of soluble carbohydrates and $\mathrm{ABA}$ in leaves (Nikinmaa et al. 2013; Mitchell et al. 2017) and trigger stomatal closure (Ainsworth and Bush 2011). ABA is transported from leaves to roots in the phloem sap (Hoad 1995) and recirculated to the shoot via the xylem (Slovik et al. 1995). ABA independently controls root and leaf growth, which affects the ratio between the two. Since phloem sap concentration of ABA is increased in drought-stressed plants (Hoad 1973), Munns and Cramer (1996) suggested that leaves regulate root growth by feedforward control via hormonal signals in phloem sap. On the other hand, reduced phloem transport in drought-stressed trees could lead to an accumulation of leaf-produced ABA in the foliage of water-stressed trees (Mitchell et al. 2017), exerting a feedback control on leaf expansion and stomatal conductance.

As drought intensity and duration further increase, most species show a reduction or cessation of photosynthesis as stomata close in order to decrease the risk of embolism ( $\mathrm{Li}$ et al. 2016). This can lead to a source-limited slowdown of phloem transport (Figure 2). From a theoretical point-of-view, this means that the overall transport need and transport rates of sugars are smaller as drought decreases loading (see above), and possibly unloading in response to decreased sink activity (growth, respiration, storage, see above). While, existing evidence clearly shows that changes in tree source-sink balance during drought will lead to a slowdown of phloem transport (Table 1), we call for systemic studies of sink and source limitations of phloem transport as a function of drought stress and the possible tipping points when the osmotic and turgor gradients in the phloem become too small to allow for functional phloem transport. Such data would allow for improved modelling of phloem response to drought. 
(3) How do drought-induced changes in water balance between xylem and phloem affect phloem transport?

The degree of osmoregulation needed, and the potential impact of increasing viscosity on phloem transport depends on how elastic the sieve elements are and how hydraulically isolated the phloem conduits are from their surroundings. The phloem tissue is known to be rather elastic (low elastic modulus, Kallarackal and Milburn 1985), and there is experimental evidence in grasses that the sieve element cell walls are more elastic than companion cell walls (Torode et al. 2018). Difference in sieve element elasticity may also exist between cell types in the phloem of trees, and among tree species, especially between gymnosperms and angiosperms, but there are only few attempts to measure elasticity of sieve elements in trees (Lee 1981; Sovonick-Dunford et al. 1983; Wright and Fisher 1983), and none has addressed its plastic response to drought. Cell wall elasticity can protect phloem against turgor loss to some extent (Pfautsch et al. 2015) allowing maintenance of turgor when water is lost to the xylem better than rigid cell walls (balloon effect). However, this comes at the cost of reduced conductivity due to the decrease in diameter of shrinking cells. Hydraulic connection between phloem conduits and the adjacent tissues reduces the influence of viscosity on flow resistance by diluting the solution using water from adjacent tissues (Sevanto 2014). However, to maintain the turgor gradient between the source and the sink, carbohydrates would need to be loaded to the stream along the pathway. To allow phloem transport according to the pressure-flow theory, phloem conduit walls cannot be fully impermeable (Minchin and Lacointe 2005), but the degree of permeability is unknown for most species. Phloem conduit walls in some trees contain protein markers for aquaporins (Stanfield et al. 2017), which suggests that conduit walls are permeable to water, and that plants may be able to control the degree of phloem conduit wall leakage (Chaumont and Tyerman 2014).

There is also clear evidence from labelling experiments (Epron et al. 2016; Furze et al. 2018) that carbohydrates can be exchanged with surrounding tissues along the phloem (Figure 1). However, data to parametrize this exchange, understand the dynamics and quantify the responses to drought are lacking (see Box 1 on the topic of modelling leaky phloem). Thus, we can only speculate about potential effects of a leaky phloem during drought: On the one hand, it could buffer the effect of drought and help maintain a functional phloem by allowing regulating the osmotic and turgor gradients driving phloem transport. On the other hand, if it is an active process requiring energy, it could become impaired as drought progresses and supply of new photoassimilates would become limited further threatening the ability of trees to maintain a functional phloem.

To reduce the influence of osmoregulatory needs on phloem sap viscosity during drought, plants could transport carbohydrates that increase viscosity less than sucrose (Lintunen et al. 2016), or use other substances such as salts to achieve the needed osmoregulation (Grange and Peel 1978; Smith and Milburn 1980). During water stress the proportion of hexoses and other solutes in the transport phloem has been found to increase in several species, such as oak, pine, spruce, aspen, birch and Douglas-fir (Woodruff 2014; Lintunen et al. 2016) (Thompson and Zwieniecki 2005). At a given concentration, dissolved hexose has a smaller viscosity in 
comparison to sucrose, and for dissolved potassium the viscosity is even smaller (Lang 1983; Hölttä et al. 2009). Provided that photosynthesis is maintained, the substitution of transport sugars with other osmolytes to maintain hydraulic equilibrium (i.e. water potential equilibrium) between the xylem and the phloem and facilitate phloem transport under drought would require sugar storage in leaves while export of photoassimilates is downregulated. A difference in this capacity between anisohydric tree species doing photosynthesis at low leaf water potentials and isohydric tree species that close stomata early during drought has indeed been observed (Dickman et al. 2015), supporting the idea of the importance of lowering the viscosity effects of the osmolytes by reducing the proportion of carbohydrates among them.

Although not all trees are likely to be equal in terms of the ability their phloem to cope with drought, available data are still too scarce to differentiate responses according to their growth strategy (e.g. slow growing versus fast growing species), their phylogenetic position (e.g. angiosperms versus gymnosperms), or their stomatal behaviour (isohydric versus anisohydric). Although we are largely unaware of these differences in terms of the effect of drought on phloem transport, overall, exiting evidence points toward phloem ability to maintain its function under most drought conditions through regulation of phloem conduit wall permeability and balancing osmoregulation with the resulting increase in viscosity. However, if conditions become too extreme for maintaining this balance, phloem function might become impaired (see mortality section).

\section{Does drought impact phloem-located defences?}

Phloem as a resource-rich tissue is often targeted by pest and pathogens (see below) and thus has evolved defence mechanisms to cope with such attacks. How these phloem defences are affected by drought is key for a tree's ability to maintain a functional phloem and survive drought.

The phloem defence responses of a tree depend on carbon source-sink relationships (see above: how phloem transport is affected by drought) and relocation of resources, either towards wounded tissues to support defence or away to protect them from the attackers (Schultz et al. 2013; Savage et al. 2016). Carbon and nutrient investments in defence could be enhanced during mild drought when growth is impaired but photosynthesis is still active (Figure 2). However, recent advances in this field challenge the existence of a trade-off between growth and defence (Porth et al. 2018). Nonetheless, carbon and nutrient investments in defence are assumed to suffer from carbon limitation during long-lasting drought (Steele et al. 1995; Netherer et al. 2015; Hartmann and Trumbore 2016), and from changes in plant nutrient uptake and stoichiometry during drought (see Gessler et al. 2017 for a recent review). Furthermore, the phloem transports both secondary metabolites such as defence compounds produced in other tissues, and resources for local inducible defences (Turgeon and Wolf 2009) and is therefore playing a central role in a tree's ability to respond to biotic attacks. However, no consistent pattern of resource allocation during biotic attacks has yet emerged from published results (Schultz et al. 2013). Therefore, how tree defensive systems are traded-off against other vital processes and are altered under drought is, yet, still a mainly unanswered question. Further research on phloem-located defence mechanisms during drought should comprise controlled experiments that investigate the interactive 
effects of drought and biotic attacks on phloem function over time. It will be important to focus on the activity and expression of whole defence-related gene families before expanding on single specific defence compounds (Wallin and Raffa 2001; Porth et al. 2018). Measurements of anatomical factors alone (e.g. lesion length, cell enlargement) are likely to not provide a sufficient picture about the trees' defensive responses (Arango-Velez et al. 2014). Finally, angiosperm tree species are largely underrepresented in studies on phloem-located defence to biotic attacks. Yet, given their global ecological and economic importance, there is a need to include more and more angiosperm tree species in further studies.

Even if the mechanisms underlying phloem defence response to drought are not well understood, published studies suggest that often, inducible defences (which comprise structural defences e.g., early lignification of fibers, formation of callus tissues, resin ducts, lesions, or wound periderms, which can directly influence phloem function (Keeling and Bohlmann 2006) and chemical defences e.g., expression of enzymes, phenolics, terpenoids, alkaloids and volatile organic compounds (Franceschi et al. 2005; Keeling et al. 2008)) are found to be impaired by drought while constitutive defences (production of a suite of defense compounds e.g., terpenoids, phenolics, alkaloids, resins, and enzymes such as chitinases) and mechanical adaptations of the bark (Franceschi et al. 2005) appear to be enhanced (Lorio et al. 1995; Lombardero et al. 2000; Lusebrink et al. 2011; Gao et al. 2017; Klutsch et al. 2017) (Table 2). For example, genes of both the terpene-synthase and chitinase families were upregulated in individuals of Pinus banksiana x Pinus contorta under water limitation (Arango-Velez et al. 2014). It also appears that the secondary phloem, such as polyphenolic parenchyma cells in conifers, is central to both inducible and constitutive defences (Franceschi et al. 2000; Franceschi et al. 2005). Additionally, the presence of ABA in the phloem of trees under mild drought might negatively affect aphid fecundity (Kerchev et al. 2013; Foyer et al. 2016) suggesting the existence of crosstolerance to both mild drought and aphids, that requires further investigations.

\section{What are the consequences of phloem response to drought?}

The phloem is located at the heart of a complex network of interacting processes (Savage et al. 2016). Therefore, when its function is impacted by drought, it will have large consequences for the tree and its environment ranging from changes in carbon allocation within the tree to changes in ecosystem carbon cycling and tree and forest mortality. There is increasing evidence that changes in phloem physiology under drought have consequences for the whole community of organisms around the tree. Finally, based on the theoretical understanding of phloem role and function, research frontiers concerning major consequences of phloem response to drought arise.

\section{Is the phloem involved in drought-induced mortality?}

Even if direct evidence of the contribution of phloem failure to tree mortality is currently lacking, phloem responses to drought are thought to be important for predicting plant mortality under drought (Sala et al. 2010; McDowell 2011; Hartmann et al. 2013a; Sevanto 2014; Sevanto et al. 2014; Salmon et al. 2015; Hartmann et al. 2018). If phloem transport ceases, plant survival time might decline even if the whole plant carbohydrate 
reserves are not completely consumed (Sala et al. 2010) because carbon cannot be delivered to tissues in need. Currently, there is no direct evidence on phloem transport ceasing or continuing during severe drought, or it impacting plant survival time, but several indirect evidences point towards a role of phloem in drought mortality.

The indirect empirical evidence of phloem transport failure comes from detection of severe shrinkage of phloem tissue prior to mortality (Sevanto et al. 2014), indirect measurement of phloem turgor loss (Salmon et al. unpublished data), lack of labelled carbohydrate detection in phloem sap and stem respiration after pulse labelling with either ${ }^{13} \mathrm{C}$ (Dannoura et al. 2019) or ${ }^{11} \mathrm{C}$ (Hubeau et al. 2019), total depletion of carbohydrates in the roots of Norway spruce, while the canopy does not suffer reserve depletion (Hartmann et al. 2013b). While Sevanto et al. (2014) study support the view of phloem turgor collapse and the role of osmoregulation in maintaining turgor, phloem flow rates were not measured at the time of expected phloem failure (Sevanto et al. 2014). Consequently, how much shrinkage of phloem tissue or apparent loss of turgor can occur before transport ceases remains unknown. However, phloem transport could also cease independently of turgor loss, if the loading and unloading are insufficient to maintain the turgor gradient generating the phloem flow. Similarly, even if evidence of reduced carbohydrate pools e.g. in root tissue indicate slow or no phloem transport (Hartmann et al. 2013a; Hartmann et al. 2013b), more direct measurements based on the detection of labelled carbohydrates (Dannoura et al. 2019; Hubeau et al. 2019) are needed to confirm cessation of transport in a wider range of tree species, and the possible reasons for it. Intriguingly, in at least some species the effect of carbohydrate reserves on plant survival time (O'Brien et al. 2014) could arise from varying access to reserves or varying phloem transport capacity among plants in the same environment (Sevanto et al. 2014).

There are some attempts to evaluate how to model and identify the main limiting factors of phloem transport under severe drought for different types of plants. The most common view for herbaceous plants seems to be a model in which conduit walls are permeable to water (i.e., water is exchanged along the entire length of conduits), but carbohydrates are loaded and unloaded only in certain areas ('semi-permeable phloem', Knoblauch and Peters 2010; Knoblauch and Peters 2017). This model suggests that plants are susceptible to turgor loss, which hinders the phloem flow at low xylem water potentials or during prolonged drought when carbohydrate reserves decline below the limit needed for effective osmoregulation (Sevanto 2014; Sevanto et al. 2014). For trees, the model used might vary between the 'semi-permeable phloem' and models in which conduit walls are non-permeable with loading and unloading zones where material exchange occurs, as well as the degree to which the model can be modified (Sevanto et al. 2018). However most of the conclusions about trees seem to be speculative or hypothetical because of a lack of empirical evidence (Sevanto 2014; Malone et al. 2016; Sevanto et al. 2018). Furthermore, there are many open questions concerning the conduit wall permeability, conduit location in relation to other cell types in the phloem, as well as the relevance of these anatomical features for phloem function under environmental stress (De Schepper et al. 2013; Savage et al. 2016). In addition, loss of xylem hydraulic conductivity during drought reduces the amount of xylem water content. Therefore, less water is available to move from xylem to phloem. But how it alters phloem transport 
remains unclear and probably varies among species depending on their vulnerability to cavitation. These points need to be addressed before we can claim full understanding of limitations in phloem transport and their impact on plant performance under drought.

\section{Drought impact on phloem feeding pests and pathogens}

Biotic agents are known to play a major role in tree drought-induced mortality (McDowell et al. 2008, 2011), and the phloem defence mechanisms are at least partially impacted by drought (see above) making trees more vulnerable to attacks. Attacks of phloem-feeding insects and accompanying pathogens play an important role for phloem functioning under water limited conditions and vice-versa. Outbreaks of phloem-feeding insects have been found to be associated with drought and elevated temperature in many studies (Anderegg et al. 2015b; White 2015). Therefore, it has been assumed that a stressed physiological state of the tree leads to outbreaks of phloem-feeding insects (White 1969; Whyte et al. 2016). Herbivore attraction is proposed to be mediated by the osmotic adjustment of phloem sap (Table 2, see also effect of water balance on phloem transport section) and neighboring tissues (Huberty and Denno 2004; Flaherty et al. 2011). Since impaired protein synthesis under drought can lead to increased concentrations of nitrogen-containing compounds in phloem sap (Table 2), the phloem attractiveness for phloem-feeding insects increases, further threatening phloem transport in drought-stressed trees (Hsiao 1973; Huberty and Denno 2004; Flaherty et al. 2011). Insects that directly influence phloem transport under drought stress (secondary agents; Six et al. 2011; Jactel et al. 2012) can be divided into phloem-sap feeders (Hemiptera, from here on: sap feeders; Huberty and Denno 2004; Pompon et al. 2011) and cambium-feeding beetles (White 2015).

Sap feeders feed on the phloem via the insertion of a stylet leading to minimized structural damage (Will et al. 2009; Will et al. 2013), but depleted sugar and nitrogen concentrations in the sap. Strong and continuous drought stress has been shown to be unfavorable for sap feeders (Björkman 2000; Huberty and Denno 2004) since (1) it makes sieve tubes more difficult to find because of lower rates of leakage (Pritchard et al. 2007), (2) decreased turgor (see above, Figure 2) reduces the accessibility of the sap (Huberty and Denno 2004), and (3) increases in viscosity (see above, Figure 2) further impair sap extraction (Isaacs et al. 1998; Pritchard et al. 2007). Whether intermittent drought is more favorable to sap feeders (Huberty and Denno 2004) or not (Mcvean and Dixon 2001; Hale et al. 2003; Pritchard et al. 2007; Mody et al. 2009) remains an open question. Cambium-feeding beetles, of which only few species are very destructive, mostly colonize trees with an impaired defence system due to drought or other environmental stresses (Franceschi et al. 2005; Bentz et al. 2010; Ryan et al. 2015; White 2015, see above). The most drought-stressed trees often are the most impacted (Breshears et al. 2005; Wermelinger et al. 2008; Kleinman et al. 2012; White 2015). The larvae of cambiumfeeding beetles destroy the phloem and cambium cells (Flaherty et al. 2011) thereby increasing the disruption of phloem translocation under drought (Franceschi et al. 2005). Therefore, impaired phloem means decreased phloem defense and higher vulnerability to biotic attack, which in turn increases phloem disruption. Despite the relatively well established effects on drought on the two main types of biotic agents affecting phloem 
(Table 2), many important questions remain unanswered, for example: are cambium-feeding beetles the true cause of tree mortality under drought? How many beetles per tree does it take to critically harm a tree (see Waring and Pitman 1985)? And, if the role of aggregation pheromones in insect response has been extensively studied (Wood 1982; Erbilgin et al. 2003; Raffa et al. 2005), how do the insects first identify the most droughtstressed trees remains unknown - is it just by chance or a directed movement?

\section{Drought-affected phloem: implications for mutualism and competition}

In addition to pest and pathogens, trees are interacting with other biotic organisms. Trees are often associated with mutualists (e.g., mycorrhiza) which offer benefits (e.g., protection, increased nutrient uptake, pollination, seed dispersal) to the trees in exchange for carbohydrates and can therefore be considered as an additional carbon sink competing with growth and storage especially under stressed conditions. These mutualistic relations have recently been reviewed by Pringle (2016), but we summarize a few of the key points related to phloem under drought. Under drought stress, carbon allocation to mutualistic organisms (e.g., pollinators and dispersers) which do not feedback on the ability of trees to maintain a normal carbon-water relation is expected to decrease (Pringle 2016). Indeed phloem flow towards fruits was shown to decrease in pear trees under water stress providing less reward to seed dispersers (Morandi et al. 2014). The picture is likely more complex for mutualistic organisms providing a nutritional benefit and probably depends on the balance between carbon cost and nutritional benefit which can be highly variable (Lendenmann et al. 2011). In legumes, symbiotic nitrogen fixation has been shown to decrease prior to photosynthesis (Serraj et al. 1999), suggesting that phloem transport towards this mutualistic carbon sink was down-regulated. Mycorrhiza appear to hold back phosphorous under low carbon supply from the plant (Hammer et al. 2011) possibly leading to tree nutrient deficiency under dry conditions (see Gessler et al. 2017 for a recent review). However, maintaining carbon allocation towards rhizobia and mycorrhiza also increased water use efficiency and possibly photosynthesis in Boswellia papyrifera (Birhane et al. 2012), which should be beneficial for the plants under drought despite the carbon cost.

\section{Research frontiers about the impact of phloem response to drought on ecosystem function}

In addition to the previously mentioned consequences of phloem response to drought, several key ecosystem processes are expected to be strongly affected by phloem function. However, experimental evidence is limited. Therefore, we strongly encourage research in these areas to improve our understanding of tree responses to drought and the role of phloem in tree and ecosystem function.

Competitive or facilitative interactions with other trees are expected to influence the changes in phloem transport (Salmon et al. 2018) and allocation under drought based on optimal partitioning models of biomass allocation (Franklin et al. 2012). However, experimental data on carbon allocation under both competition and drought stress are extremely rare (for a rare example of such study see Hommel et al. 2016). Furthermore, even across different speciesindividuals trees can donate and others receive large amounts of carbon through their rooting system (Klein et al. 2016). How widespread this ability is remains unknown, 
however. Furthermore, how such carbon exchange might respond to drought is an open question, but must depend on the trees' ability to maintain a functional phloem. Therefore, the role of phloem in shaping tree community and their environment needs to be further investigated, particularly under drought conditions.

The impact of drought on the carbon cycle of forest ecosystems is substantial and results in altered fluxes and productivity (Reichstein et al. 2013; Anderegg et al. 2015c; Doughty et al. 2015). The role of phloem function in these ecosystem responses, however, remains unresolved (Savage et al. 2016). Since the phloem connects the major ecosystem carbon source with the major ecosystem carbon sinks (Högberg et al. 2001) it can be assumed to represent an important piece in the ecosystem carbon cycle (Savage et al. 2016). Theoretical predictions based on our understanding of phloem transport suggest that decreased source and sink activities and increases in phloem sugar concentration and viscosity should slow phloem transport under drought (see above). There is some experimental support for predictions (Ruehr et al. 2009; Barthel et al. 2011; Zang et al. 2014) but most of these experiments were performed on potted seedlings of a very limited number of species, and experiments performed with different drought intensity, different species, at different developmental stages or in more natural settings were not always conclusive (Epron et al. 2011; Epron et al. 2016; Hommel et al. 2016). Furthermore, the complexity of the processes involved in heterotrophic respiration (e.g., exudation, diffusion of $\mathrm{CO}_{2}$ to the soil surface, Stoy et al. 2007; Risk et al. 2012) might further limit our understanding of phloem contribution to ecosystems respiration. As mentioned above, root exudation has been found to increase at low water stress (Reid and Mexal 1977), but to decrease when drought intensity increases (Reid 1974).The contribution of recent photoassimilates to the overall exudation flux remains unclear (Karst et al. 2017) calling for more systemic studies of carbon fluxes under drought across a large range of species, development stage, growing conditions are needed. Additionally, to improve our understanding of the role of phloem transport in ecosystem biogeochemical cycles we need to: 1) develop methods to study phloem in the field (Savage et al. 2016), and 2) conduct field experiments with mature trees. In particular, the rarely investigated phloem responses to experimental precipitation manipulations (Epron et al. 2016) could provide an ideal setup to test the effect of water stress on carbon flow as it has been done with water flow (Grossiord et al. 2017).

\section{Summary and conclusions}

In the present review, we demonstrate that phloem is resistant to mild drought (Figure 2), but as the stress becomes more severe and particularly under acute drought, phloem function becomes affected as the multiple processes regulating it become impaired. This conclusion suggests that trees have sought to maintain homeostasis of phloem transport for as long as they can. Due to their long life span, it is almost certain that most trees will experience mild drought at some point. Supporting this idea, given the importance of phloem transport for tree function, it is highly probable that trees developed a phloem resistant to drought.

Despite the great capability of trees to maintain a functional phloem during drought, three main effects of drought have been recorded in severely drought-stressed trees: 1) a decreased phloem transport rate; 2) an 
increased sugar concentration of the phloem sap; and 3) changes in phloem anatomy towards smaller sieve elements. These three responses to drought are obviously interacting and in agreement with predictions that can be made from the pressure-flow model and the Lockhart equation. However, the relative importance of the different factors reducing phloem transport rate (e.g., decrease conductivity, decreased source-sink gradient, increases in phloem viscosity, collapse of turgor) is yet to be analysed. Nonetheless, even though the theory of phloem transport is fairly well understood, attempts to quantify and model processes related to loading, unloading, and reloading of carbohydrates, water exchange between phloem conduits, and the consequences of these processes on phloem function under drought, suffer from the lack of available data. Among research directions that would provide us with the lacking information on limitations of phloem function under drought and its impacts on plant function and survival we suggest priority to these four of them: [1] the responses of sink tissues to drought and their consequences on phloem unloading; [2] the relation between loading strategies (apoplastic versus symplastic) and drought tolerance has not yet been explored, [3] the difference in phloem behaviour under drought along the continuum between isohydric and anisohydric species; [4] how loss of xylem hydraulic conductivity during drought feeds back on phloem transport. Even if the hypothesized importance of phloem failure in tree mortality makes sense based on the pressure-flow theory, few studies have experimentally addressed this question to offer a definitive answer to this question leaving answers on when, how, and why phloem would fail remain mostly hypothetical. A research frontier worth investigating is how sensitive to phloem failure trees might be in comparison to other potential causes of mortality (e.g., hydraulic failure) during drought stress, and how these causes interact with each other.

It is also striking that only a few studies have investigated phloem under drought over the last decades (Table 1), which means that most of our knowledge is based on studies of seedlings of very few species, with Fagus sylvatica alone being investigated in almost one third of the studies. From our understanding of tree and ecosystem functioning, it can be expected that any disruption of phloem transport under drought has a strong impact on the ecosystem functioning. Biotic attacks have been one of the factors considered central to studies of drought-induced mortality. The damage brought to the phloem by pest and pathogens and how trees defend themselves against such attacks has received a lot of attention, and despite numerous open questions (see above), it is clear that sap feeders are suffering from drought and thus minimizing their damage to the phloem while the opposite is true for cambium feeders (Table 2). Beyond biotic attacks, the ecological impact of phloem response to drought is a topic that has barely been investigated. Overall, from our understanding of tree physiology it seems clear that phloem must play a crucial role in shaping the biotic relationships of trees under drought by controlling or constraining resource allocation both within trees and ecosystems. However, the limited amount of empirical data or modelling attempts limits our ability to predict what that role might exactly be. Furthermore, because phloem transport is central to many ecosystem functions and the main link between carbon source and sink, understanding how phloem responds to drought and how it affects the carbon cycle in ecosystems would help improve predictions of drought impact in large scale models (e.g., landsurface-atmosphere or dynamic vegetation models). However, two challenges need to be overcome to 
601

602

603

604

605

606

607

608

609

610

611

612

613

614

615

616

617

618

619

620

621

622

623

624

625

626

627

628

629

implement phloem transport into models at scales beyond individual trees: (1) building a simple, computationally cheap formulation of phloem transport models, and then (2) obtaining experimental data to parameterize such models across a large number of species, growth stages and environmental conditions. Thus, only a better understanding of phloem physiology and the cost-benefit relation between trees and other organisms will allow us to understand how phloem responses to drought shape ecological interactions and constrain biogeochemical cycles.

\section{Acknowledgment}

YS was supported by the Academy of Finland (project \#312571). SS was supported by the Los Alamos National Laboratory LDRD Project \#20160373ER. UMR (Unité Mixte de Recherche) Silva (DE) is supported by a grant overseen by the French National Research Agency (ANR) as part of the program "Investissements d'Avenir" (ANR-11-LABX-0002-01, Laboratory of Excellence ARBRE).

\section{References}

Adams HD, Zeppel MJB, Anderegg WRL, Hartmann H, Landhäusser SM, Tissue DT, Huxman TE, Hudson PJ, Franz TE, Allen CD, Anderegg LDL, Barron-Gafford GA, Beerling DJ, Breshears DD, Brodribb TJ, Bugmann H, Cobb RC, Collins AD, Dickman LT, Duan H, Ewers BE, Galiano L, Galvez DA, GarciaForner N, Gaylord ML, Germino MJ, Gessler A, Hacke UG, Hakamada R, Hector A, Jenkins MW, Kane JM, Kolb TE, Law DJ, Lewis JD, Limousin J-M, Love DM, Macalady AK, Martínez-Vilalta J, Mencuccini M, Mitchell PJ, Muss JD, O'Brien MJ, O'Grady AP, Pangle RE, Pinkard EA, Piper FI, Plaut JA, Pockman WT, Quirk J, Reinhardt K, Ripullone F, Ryan MG, Sala A, Sevanto S, Sperry JS, Vargas R, Vennetier M, Way DA, Xu C, Yepez EA, McDowell NG (2017) A multi-species synthesis of physiological mechanisms in drought-induced tree mortality. Nature Ecology \& Evolution. 1:1285-1291.

Ainsworth EA, Bush DR (2011) Carbohydrate export from the leaf: a highly regulated process and target to enhance photosynthesis and productivity. Plant Physiology. 155:64-69.

Allen CD, Macalady AK, Chenchouni H, Bachelet D, McDowell N, Vennetier M, Kitzberger T, Rigling A, Breshears DD, Hogg EH, Gonzalez P, Fensham R, Zhang Z, Castro J, Demidova N, Lim J-H, Allard G, Running SW, Semerci A, Cobb N (2010) A global overview of drought and heat-induced tree mortality reveals emerging climate change risks for forests. Forest Ecology and Management. 259:660-684.

Anderegg WRL, Flint A, Huang C-y, Flint L, Berry JA, Davis Frank W, Sperry JS, Field CB (2015a) Tree mortality predicted from drought-induced vascular damage. Nature Geoscience. 8:367.

Anderegg WRL, Hicke JA, Fisher RA, Allen CD, Aukema J, Bentz B, Hood S, Lichstein JW, Macalady AK, McDowell N, Pan Y, Raffa K, Sala A, Shaw JD, Stephenson NL, Tague C, Zeppel M (2015b) Tree mortality from drought, insects, and their interactions in a changing climate. New Phytol. 208:674683.

Anderegg WRL, Schwalm C, Biondi F, Camarero JJ, Koch G, Litvak M, Ogle K, Shaw JD, Shevliakova E, Williams AP, Wolf A, Ziaco E, Pacala S (2015c) Pervasive drought legacies in forest ecosystems and their implications for carbon cycle models. Science. 349:528-532.

Arango-Velez A, González LMG, Meents MJ, El Kayal W, Cooke BJ, Linsky J, Lusebrink I, Cooke JEK (2014) Influence of water deficit on the molecular responses of Pinus contorta $\times$ Pinus banksiana mature trees to infection by the mountain pine beetle fungal associate, Grosmannia clavigera. Tree Physiol. 34:1220-1239.

Arndt SK, Livesley SJ, Merchant A, Bleby TM, Grierson PF (2008) Quercitol and osmotic adaptation of fieldgrown Eucalyptus under seasonal drought stress. Plant, Cell \& Environment. 31:915-924. 
Atkin OK, Macherel D (2009) The crucial role of plant mitochondria in orchestrating drought tolerance. Annals of Botany. 103:581-597.

Barthel M, Hammerle A, Sturm P, Baur T, Gentsch L, Knohl A (2011) The diel imprint of leaf metabolism on the $\delta^{13} \mathrm{C}$ signal of soil respiration under control and drought conditions. New Phytol. 192:925-938.

Bentz BJ, Régnière J, Fettig CJ, Hansen EM, Hayes JL, Hicke JA, Kelsey RG, Negrón JF, Seybold SJ (2010) Climate change and bark beetles of the western United States and Canada: direct and indirect effects. BioScience. 60:602-613.

Berninger F, Hari P, Nikinmaa E, Lindholm M, Meriläinen J (2004) Use of modeled photosynthesis and decomposition to describe tree growth at the northern tree line. Tree Physiol. 24:193-204.

Birhane E, Sterck FJ, Fetene M, Bongers F, Kuyper TW (2012) Arbuscular mycorrhizal fungi enhance photosynthesis, water use efficiency, and growth of frankincense seedlings under pulsed water availability conditions. Oecologia. 169:895-904.

Björkman C (2000) Interactive effects of host resistance and drought stress on the performance of a gallmaking aphid living on Norway spruce. Oecologia. 123:223-231.

Blessing CH, Barthel M, Gentsch L, Buchmann N (2016) Strong coupling of shoot assimilation and soil respiration during drought and recovery periods in beech as indicated by natural abundance $\delta^{13} \mathrm{C}$ measurements. Front Plant Sci. 7:12.

Blessing CH, Werner RA, Siegwolf R, Buchmann N (2015) Allocation dynamics of recently fixed carbon in beech saplings in response to increased temperatures and drought. Tree Physiol. 35:585-598.

Bloom AJ, Chapin III FS, Mooney HA (1985) Resource Limitation in Plants-An Economic Analogy. Annual Review of Ecology and Systematics. 16:363-392.

Breshears DD, Cobb NS, Rich PM, Price KP, Allen CD, Balice RG, Romme WH, Kastens JH, Floyd ML, Belnap J, Anderson JJ, Myers OB, Meyer CW (2005) Regional vegetation die-off in response to global-changetype drought. Proceedings of the National Academy of Sciences of the United States of America. 102:15144-15148.

Brilli F, Barta C, Fortunati A, Lerdau M, Loreto F, Centritto M (2007) Response of isoprene emission and carbon metabolism to drought in white poplar (Populus alba) saplings. New Phytol. 175:244-254.

Brunner I, Herzog C, Dawes MA, Arend M, Sperisen C (2015) How tree roots respond to drought. Front Plant Sci. 6

Brüggemann N, Gessler A, Kayler Z, Keel SG, Badeck F, Barthel M, Boeckx P, Buchmann N, Brugnoli E, Esperschütz J, Gavrichkova O, Ghashghaie J, Gomez-Casanovas N, Keitel C, Knohl A, Kuptz D, Palacio S, Salmon Y, Uchida Y, Bahn M (2011) Carbon allocation and carbon isotope fluxes in the plant-soilatmosphere continuum: a review. Biogeosciences. 8:3457-3489.

Cabrita P, Thorpe M, Huber G (2013) Hydrodynamics of steady state phloem transport with radial leakage of solute. Front Plant Sci. 4

Chaumont F, Tyerman SD (2014) Aquaporins: Highly regulated channels controlling plant water relations. Plant Physiology. 164:1600-1618.

Ciais P, Reichstein M, Viovy N, Granier A, Ogée J, Allard V, Aubinet M, Buchmann N, Bernhofer C, Carrara A, Chevallier F, De Noblet N, Friend AD, Friedlingstein $P$, Grünwald T, Heinesch B, Keronen $P$, Knohl A, Krinner G, Loustau D, Manca G, Matteucci G, Miglietta F, Ourcival JM, Papale D, Pilegaard K, Rambal S, Seufert G, Soussana JF, Sanz MJ, Schulze ED, Vesala T, Valentini R (2005) Europe-wide reduction in primary productivity caused by the heat and drought in 2003. Nature. 437:529.

Cosgrove DJ (1993) Wall extensibility: its nature, measurement and relationship to plant cell growth. New Phytol. 124:1-23.

Dai AG (2013) Increasing drought under global warming in observations and models. Nat Clim Chang. 3:5258.

Dannoura M, Epron D, Desalme D, Massonnet C, Tsuji S, Caroline P, Priault P, Gérant D (2019) The impact of prolonged drought on phloem anatomy and phloem transport in young beech trees. Tree Physiol

Dannoura M, Maillard P, Fresneau C, Plain C, Berveiller D, Gerant D, Chipeaux C, Bosc A, Ngao J, Damesin C, Loustau D, Epron D (2011) In situ assessment of the velocity of carbon transfer by tracing ${ }^{13} \mathrm{C}$ in trunk $\mathrm{CO}_{2}$ efflux after pulse labelling: variations among tree species and seasons. New Phytol. 190:181-192. 
Davidson A, Keller F, Turgeon R (2011) Phloem loading, plant growth form, and climate. Protoplasma. 248:153-163.

De Schepper V, De Swaef T, Bauweraerts I, Steppe K (2013) Phloem transport: a review of mechanisms and controls. J Exp Bot. 64:4839-4850.

De Schepper V, Steppe K (2010) Development and verification of a water and sugar transport model using measured stem diameter variations. J Exp Bot. 61:2083-2099.

Desalme D, Priault P, Gérant D, Dannoura M, Maillard P, Plain C, Epron D (2017) Seasonal variations drive short-term dynamics and partitioning of recently assimilated carbon in the foliage of adult beech and pine. New Phytol. 213:140-153.

Dickman LT, McDowell NG, Sevanto S, Pangle RE, Pockman WT (2015) Carbohydrate dynamics and mortality in a piñon-juniper woodland under three future precipitation scenarios. Plant, Cell \& Environment. 38:729-739.

Doughty CE, Metcalfe DB, Girardin CAJ, Amézquita FF, Cabrera DG, Huasco WH, Silva-Espejo JE, AraujoMurakami A, da Costa MC, Rocha W, Feldpausch TR, Mendoza ALM, da Costa ACL, Meir P, Phillips OL, Malhi Y (2015) Drought impact on forest carbon dynamics and fluxes in Amazonia. Nature. 519:78.

Durand M, Porcheron B, Hennion N, Maurousset L, Lemoine R, Pourtau N (2016) Water deficit enhances C export to the roots in Arabidopsis thaliana plants with contribution of sucrose transporters in both shoot and roots. Plant Physiology. 170:1460-1479.

Epron D, Bahn M, Derrien D, Lattanzi FA, Pumpanen J, Gessler A, Hogberg P, Maillard P, Dannoura M, Gerant D, Buchmann N (2012) Pulse-labelling trees to study carbon allocation dynamics: a review of methods, current knowledge and future prospects. Tree Physiol. 32:776-798.

Epron D, Cabral OMR, Laclau JP, Dannoura M, Packer AP, Plain C, Battie-Laclau P, Moreira MZ, Trivelin PCO, Bouillet JP, Gerant D, Nouvellon Y (2016) In situ ${ }^{13} \mathrm{CO}_{2}$ pulse labelling of field-grown eucalypt trees revealed the effects of potassium nutrition and throughfall exclusion on phloem transport of photosynthetic carbon. Tree Physiol. 36:6-21.

Epron D, Dannoura M, Ishida A, Kosugi Y (2019) Estimation of phloem carbon translocation belowground at stand level in a hinoki cypress stand. . Tree Physiol

Epron D, Dreyer E (1996) Starch and soluble carbohydrates in leaves of water-stressed oak saplings. Ann For Sci. 53:263-268.

Epron D, Ngao J, Dannoura M, Bakker MR, Zeller B, Bazot S, Bosc A, Plain C, Lata JC, Priault P, Barthes L, Loustau D (2011) Seasonal variations of belowground carbon transfer assessed by in situ ${ }^{13} \mathrm{CO}_{2}$ pulse labelling of trees. Biogeosciences. 8:1153-1168.

Erbilgin N, Powell JS, Raffa KF (2003) Effect of varying monoterpene concentrations on the response of Ips pini (Coleoptera: Scolytidae) to its aggregation pheromone: implications for pest management and ecology of bark beetles. Agricultural and Forest Entomology. 5:269-274.

Flaherty L, Sweeney JD, Pureswaran D, Quiring DT (2011) Influence of host tree condition on the performance of Tetropium fuscum (Coleoptera: Cerambycidae). Environmental Entomology. 40:1200-1209.

Flexas J, Bota J, Galmés J, Medrano H, Ribas-Carbó M (2006) Keeping a positive carbon balance under adverse conditions: responses of photosynthesis and respiration to water stress. Physiologia Plantarum. 127:343-352.

Foyer CH, Rasool B, Davey JW, Hancock RD (2016) Cross-tolerance to biotic and abiotic stresses in plants: a focus on resistance to aphid infestation. J Exp Bot. 67:2025-2037.

Franceschi VR, Krokene P, Christiansen E, Krekling T (2005) Anatomical and chemical defenses of conifer bark against bark beetles and other pests. New Phytol. 167:353-376.

Franceschi VR, Krokene P, Krekling T, Christiansen E (2000) Phloem parenchyma cells are involved in local and distant defense responses to fungal inoculation or bark-beetle attack in Norway spruce (Pinaceae). American Journal of Botany. 87:314-326.

Franklin O, Johansson J, Dewar RC, Dieckmann U, McMurtrie RE, Brännström Å, Dybzinski R (2012) Modeling carbon allocation in trees: a search for principles. Tree Physiol. 32:648-666. 
Frensch J, Hsiao TC (1995) Rapid response of the yield threshold and turgor regulation during adjustment of root growth to water stress in Zea mays. Plant Physiology. 108:303-312.

Frost CJ, Nyamdari B, Tsai C-J, Harding SA (2012) The tonoplast-localized sucrose transporter in Populus (PtaSUT4) regulates whole-plant water relations, responses to water stress, and photosynthesis. PLOS ONE. 7:e44467.

Furze ME, Trumbore S, Hartmann H (2018) Detours on the phloem sugar highway: stem carbon storage and remobilization. Current Opinion in Plant Biology. 43:89-95.

Gamalei Y (1991) Phloem loading and its development related to plant evolution from trees to herbs. Trees 5:50-64.

Gao X, Zhou X, Wang H, Kong X, Zhang S, Wang Z, Wu W, Zhang Z, Lieutier F (2017) Influence of severe drought on the resistance of Pinus yunnanensis to a bark beetle-associated fungus. Forest Pathol. 47:8.

Gessler A, Schaub M, McDowell NG (2017) The role of nutrients in drought-induced tree mortality and recovery. New Phytol. 214:513-520.

Girousse C, Bournoville R, Bonnemain JL (1996) Water deficit-induced changes in concentrations in proline and some other amino acids in the phloem sap of alfalfa. Plant Physiology. 111:109-113.

Grange RI, Peel AJ (1978) Evidence for solution flow in the phloem of willow. Planta. 138:15-23.

Gričar J, Čufar K (2008) Seasonal dynamics of phloem and xylem formation in silver fir and Norway spruce as affected by drought. . Russian Journal Plant Physioly. 555:538-543.

Gričar J, Krže L, Čufar K (2009) Number of cells in xylem, phloem and dormant cambium in silver fir (Abies $a l b a)$, in trees of different vitality. IAWA Journal. 30:121-133.

Gričar J, Prislan P, de Luis M, Gryc V, Hacurová J, Vavrčík H, Čufar K (2015) Plasticity in variation of xylem and phloem cell characteristics of Norway spruce under different local conditions. . Front Plant Sci. 6:730.

Gričar J, Prislan P, Gryc V, Vavrčík H, de Luis M, Čufar K (2014) Plastic and locally adapted phenology in cambial seasonality and production of xylem and phloem cells in Picea abies from temperate environments. Tree Physiol. 34:869-881.

Grossiord C, Sevanto S, Limousin J-M, Meir P, Mencuccini M, Pangle RE, Pockman WT, Salmon Y, Zweifel R, McDowell NG (2017) Manipulative experiments demonstrate how long-term soil moisture changes alter controls of plant water use. Environ Exp Bot

Hagedorn F, Joseph J, Peter M, Luster J, Pritsch K, Geppert U, Kerner R, Molinier V, Egli S, Schaub M, Liu J-F, Li M, Sever K, Weiler M, Siegwolf RTW, Gessler A, Arend M (2016) Recovery of trees from drought depends on belowground sink control. Nat Plants. 2:16111.

Hale BK, Bale JS, Pritchard J, Masters GJ, Brown VK (2003) Effects of host plant drought stress on the performance of the bird cherry-oat aphid, Rhopalosiphum padi (L.): a mechanistic analysis. Ecological Entomology. 28:666-677.

Hammer EC, Pallon J, Wallander H, Olsson PA (2011) Tit for tat? A mycorrhizal fungus accumulates phosphorus under low plant carbon availability. FEMS Microbiology Ecology. 76:236-244.

Hartmann H (2015) Carbon starvation during drought-induced tree mortality - are we chasing a myth? Journal of Plant Hydraulics. 2:e005.

Hartmann H, Moura CF, Anderegg WRL, Ruehr NK, Salmon Y, Allen CD, Arndt SK, Breshears DD, Davi H, Galbraith D, Ruthrof KX, Wunder J, Adams HD, Bloemen J, Cailleret M, Cobb R, Gessler A, Grams TEE, Jansen S, Kautz M, Lloret F, O'Brien M (2018) Research frontiers for improving our understanding of drought-induced tree and forest mortality. New Phytol. 218:15-28.

Hartmann H, Trumbore S (2016) Understanding the roles of nonstructural carbohydrates in forest trees from what we can measure to what we want to know. New Phytol. 211:386-403.

Hartmann H, Ziegler W, Kolle O, Trumbore S (2013a) Thirst beats hunger - declining hydration during drought prevents carbon starvation in Norway spruce saplings. New Phytol. 200:340-349.

Hartmann H, Ziegler W, Trumbore S, Knapp A (2013b) Lethal drought leads to reduction in nonstructural carbohydrates in Norway spruce tree roots but not in the canopy. Funct Ecol. 27:413-427.

Hoad GV (1973) Effect of moisture stress on abscisic-acid levels in Ricinus-communis $L$ with particular reference to phloem exudate. Planta. 113:367-372. 
Hoad GV (1995) Transport of hormones in the phloem of higher-plants. Plant Growth Regulation. 16:173182.

Hommel R, Siegwolf R, Zavadlav S, Arend M, Schaub M, Galiano L, Haeni M, Kayler ZE, Gessler A (2016) Impact of interspecific competition and drought on the allocation of new assimilates in trees. Plant Biol. 18:785-796.

Hsiao TC (1973) Plant responses to water stress. Annual Review of Plant Physiology and Plant Molecular Biology. 24:519-570.

Hsiao TC, Acevedo E, Fereres E, Henderson DW (1976) Water stress, growth and osmotic adjustment. Philosophical Transactions of the Royal Society of London B, Biological Sciences. 273:479-500.

Hsiao TC, Xu LK (2000) Sensitivity of growth of roots versus leaves to water stress: biophysical analysis and relation to water transport. J Exp Bot. 51:1595-1616.

Hubeau M, Mincke J, Vanhove C, Courtyn J, Vandenberghe S, Steppe K (2019) Plant-PET to investigate phloem vulnerability to drought in Populus tremula under changing climate regimes. Tree Physiol. In press

Hubeau M, Steppe K (2015) Plant-PET scans: In vivo mapping of xylem and phloem functioning. Trends in Plant Science. 20:676-685.

Huberty AF, Denno RF (2004) Plant water stress and its consequences for herbivorous insects: a new synthesis. Ecology. 85:1383-1398.

Hummel I, Pantin F, Sulpice R, Piques M, Rolland G, Dauzat M, Christophe A, Pervent M, Bouteillé M, Stitt M, Gibon Y, Muller B (2010) Arabidopsis plants acclimate to water deficit at low cost through changes of carbon usage: an integrated perspective using growth, metabolite, enzyme, and gene expression analysis. Plant Physiology. 154:357-372.

Högberg P, Nordgren A, Buchmann N, Taylor AFS, Ekblad A, Högberg MN, Nyberg G, Ottosson-Löfvenius M, Read DJ (2001) Large-scale forest girdling shows that current photosynthesis drives soil respiration. Nature. 411:789.

Hölttä T, Mencuccini M, Nikinmaa E (2009) Linking phloem function to structure: Analysis with a coupled xylem-phloem transport model. Journal of Theoretical Biology. 259:325-337.

Hölttä T, Mäkinen H, Nöjd P, Mäkelä A, Nikinmaa E (2010) A physiological model of softwood cambial growth. Tree Physiol. 30:1235-1252.

Hölttä T, Vesala T, Sevanto S, Perämäki M, Nikinmaa E (2006) Modeling xylem and phloem water flows in trees according to cohesion theory and Münch hypothesis. Trees. 20:67-78.

Isaacs R, Byrne DN, Hendrix DL (1998) Feeding rates and carbohydrate metabolism by Bemisia tabaci (Homoptera: Aleyrodidae) on different quality phloem saps. Physiological Entomology. 23:241-248.

Jactel H, Petit J, Desprez-Loustau M-L, Delzon S, Piou D, Battisti A, Koricheva J (2012) Drought effects on damage by forest insects and pathogens: a meta-analysis. Glob Change Biol. 18:267-276.

Jensen KH, Lee J, Bohr T, Bruus H, Holbrook NM, Zwieniecki MA (2011) Optimality of the Münch mechanism for translocation of sugars in plants. Journal of The Royal Society Interface. 8:1155-1165.

Jyske T, Hölttä T (2015) Comparison of phloem and xylem hydraulic architecture in Picea abies stems. New Phytol. 205:102-115.

Kallarackal J, Milburn JA (1985) Phloem sap exudation in Ricinus communis: elastic responses and anatomical implications. Plant, Cell \& Environment. 8:239-245.

Karst J, Gaster J, Wiley E, Landhäusser SM (2017) Stress differentially causes roots of tree seedlings to exude carbon. Tree Physiol. 37:154-164.

Keeling Cl, Bohlmann J (2006) Genes, enzymes and chemicals of terpenoid diversity in the constitutive and induced defence of conifers against insects and pathogens*. New Phytol. 170:657-675.

Keeling Cl, Weisshaar S, Lin RPC, Bohlmann J (2008) Functional plasticity of paralogous diterpene synthases involved in conifer defense. Proceedings of the National Academy of Sciences. 105:1085-1090.

Kerchev PI, Karpinska B, Morris JA, Hussain A, Verrall SR, Hedley PE, Fenton B, Foyer CH, Hancock RD (2013) Vitamin $C$ and the abscisic acid-insensitive 4 transcription factor are important determinants of aphid resistance in Arabidopsis. Antioxidants \& Redox Signaling. 18:2091-2105.

Klein T, Hoch G, Yakir D, Korner C (2014) Drought stress, growth and nonstructural carbohydrate dynamics of pine trees in a semi-arid forest. Tree Physiol. 34:981-992. 
Klein T, Siegwolf RTW, Körner C (2016) Belowground carbon trade among tall trees in a temperate forest. Science. 352:342-344.

Kleinman SJ, DeGomez TE, Snider GB, Williams KE (2012) Large-scale pinyon ips (ips confusus) outbreak in southwestern united states tied with elevation and land cover. Journal of Forestry,. 110:194-200.

Klutsch JG, Shamoun SF, Erbilgin N (2017) Drought stress leads to systemic induced susceptibility to a nectrotrophic fungus associated with mountain pine beetle in Pinus banksiana seedlings. PLOS ONE. 12:e0189203.

Knoblauch J, Mullendore DL, Jensen KH, Knoblauch M (2014) Pico Gauges for Minimally Invasive Intracellular Hydrostatic Pressure Measurements. Plant Physiology. 166:1271-1279.

Knoblauch M, Knoblauch J, Mullendore DL, Savage JA, Babst BA, Beecher SD, Dodgen AC, Jensen KH, Holbrook NM (2016) Testing the Münch hypothesis of long distance phloem transport in plants. eLife. 5:e15341.

Knoblauch M, Peters WS (2010) Münch, morphology, microfluidics - our structural problem with the phloem. Plant, Cell \& Environment. 33:1439-1452.

Knoblauch M, Peters WS (2017) What actually is the Münch hypothesis? A short history of assimilate transport by mass flow. J Integr Plant Biol. 59:292-310.

Kozlowski TT, Pallardy SG (2002) Acclimation and adaptive responses of woody plants to environmental stresses. The Botanical Review. 68:270-334.

Körner C (2015) Paradigm shift in plant growth control. Current Opinion in Plant Biology. 25:107-114.

Lang A (1983) Turgor-regulated translocation. Plant, Cell \& Environment. 6:683-689.

Lee DR (1981) Elasticity of phloem tissues. J Exp Bot. 32:251-260.

Lehto T, Zwiazek JJ (2011) Ectomycorrhizas and water relations of trees: a review. Mycorrhiza. 21:71-90.

Lemoine R, La Camera S, Atanassova R, Dédaldéchamp F, Allario T, Pourtau N, Bonnemain J-L, Laloi M, Coutos-Thévenot P, Maurousset L, Faucher M, Girousse C, Lemonnier P, Parrilla J, Durand M (2013) Source-to-sink transport of sugar and regulation by environmental factors. Front Plant Sci. 4

Lendenmann M, Thonar C, Barnard RL, Salmon Y, Werner RA, Frossard E, Jansa J (2011) Symbiont identity matters: carbon and phosphorus fluxes between Medicago truncatula and different arbuscular mycorrhizal fungi. Mycorrhiza. 21:689-702.

Li S, Feifel M, Karimi Z, Schuldt B, Choat B, Jansen S (2016) Leaf gas exchange performance and the lethal water potential of five European species during drought. Tree Physiol. 36:179-192.

Liesche J (2017) Sucrose transporters and plasmodesmal regulation in passive phloem loading. J Integr Plant Biol. 59:311-321.

Liesche J, Schulz A (2018) Phloem transport in gymnosperms: a question of pressure and resistance. Current Opinion in Plant Biology. 43:36-42.

Lintunen A, Paljakka T, Jyske T, Peltoniemi M, Sterck F, von Arx G, Cochard H, Copini P, Caldeira MC, Delzon S, Gebauer R, Grönlund L, Kiorapostolou N, Lechthaler S, Lobo-do-Vale R, Peters RL, Petit G, Prendin AL, Salmon Y, Steppe K, Urban J, Roig Juan S, Robert EMR, Hölttä T (2016) Osmolality and nonstructural carbohydrate composition in the secondary phloem of trees across a latitudinal gradient in Europe. Front Plant Sci. 7

Lockhart JA (1965) An analysis of irreversible plant cell elongation. Journal of Theoretical Biology. 8:264275.

Lombardero MJ, Ayres MP, Lorio JPL, Ruel JJ (2000) Environmental effects on constitutive and inducible resin defences of Pinus taeda. Ecology Letters. 3:329-339.

Lorio PL, Stephen FM, Paine TD (1995) Environment and ontogeny modify loblolly pine response to induced acute water deficits and bark beetle attack. Forest Ecology and Management. 73:97-110.

Lusebrink I, Evenden ML, Blanchet FG, Cooke JEK, Erbilgin N (2011) Effect of water stress and fungal inoculation on monoterpene emission from an historical and a new pine host of the mountain pine beetle. Journal of Chemical Ecology. 37:1013-1026.

Löf M, Bolte A, Welander NT (2005) Interacting effects of irradiance and water stress on dry weight and biomass partitioning in Fagus sylvatica seedlings. Scandinavian Journal of Forest Research. 20:322328. 
Malone MW, Yoder J, Hunter JF, Espy MA, Dickman LT, Nelson RO, Vogel SC, Sandin HJ, Sevanto S (2016) In vivo observation of tree drought response with low-field NMR and neutron imaging. Front Plant Sci. 7:9.

McDowell N, Pockman WT, Allen CD, Breshears DD, Cobb N, Kolb T, Plaut J, Sperry J, West A, Williams DG, Yepez EA (2008) Mechanisms of plant survival and mortality during drought: why do some plants survive while others succumb to drought? New Phytol. 178:719-739.

McDowell NG (2011) Mechanisms linking drought, hydraulics, carbon metabolism, and vegetation mortality. Plant Physiology. 155:1051-1059.

McDowell NG, Beerling DJ, Breshears DD, Fisher RA, Raffa KF, Stitt M (2011) The interdependence of mechanisms underlying climate-driven vegetation mortality. Trends in Ecology and Evolution. 26:523-532.

McDowell NG, Fisher RA, Xu C, Domec JC, Hölttä T, Mackay DS, Sperry JS, Boutz A, Dickman L, Gehres N, Limousin JM, Macalady A, Martínez-Vilalta J, Mencuccini M, Plaut JA, Ogée J, Pangle RE, Rasse DP, Ryan MG, Sevanto S, Waring RH, Williams AP, Yepez EA, Pockman WT (2013) Evaluating theories of drought-induced vegetation mortality using a multimodel-experiment framework. New Phytol. 200:304-321.

McKiernan AB, Potts BM, Brodribb TJ, Hovenden MJ, Davies NW, McAdam SAM, Ross JJ, Rodemann T, O'Reilly-Wapstra JM (2016) Responses to mild water deficit and rewatering differ among secondary metabolites but are similar among provenances within Eucalyptus species. Tree Physiol. 36:133147.

Mcvean RIK, Dixon AFG (2001) The effect of plant drought-stress on populations of the pea aphid Acyrthosiphon pisum. Ecological Entomology. 26:440-443.

Meier IC, Leuschner C (2010) Variation of soil and biomass carbon pools in beech forests across a precipitation gradient. Glob Change Biol. 16:1035-1045.

Mencuccini M, Hölttä T, Sevanto S, Nikinmaa E (2013) Concurrent measurements of change in the bark and xylem diameters of trees reveal a phloem-generated turgor signal. New Phytol. 198:1143-1154.

Mencuccini M, Minunno F, Salmon Y, Martínez-Vilalta J, Hölttä T (2015) Coordination of physiological traits involved in drought-induced mortality of woody plants. New Phytol. 208:396-409.

Milne RJ, Grof CPL, Patrick JW (2018) Mechanisms of phloem unloading: shaped by cellular pathways, their conductances and sink function. Current Opinion in Plant Biology. 43:8-15.

Minchin PEH, Lacointe A (2005) New understanding on phloem physiology and possible consequences for modelling long-distance carbon transport. New Phytol. 166:771-779.

Minchin PEH, Lacointe A (2017) Consequences of phloem pathway unloading/reloading on equilibrium flows between source and sink: a modelling approach. Functional Plant Biology. 44:507-514.

Minchin PEH, Lang A, Thorpe MR (1983) Dynamics of cold induced inhibition of phloem transport. J Exp Bot. 34:156-162.

Minchin PEH, Thorpe MR (1987) Is phloem transport due to a hydrostatic-pressure gradient - supporting evidence from pressure chamber experiments. Australian Journal of Plant Physiology. 14:397-402.

Minchin PEH, Thorpe MR, Farrar JF (1993) A simple mechanistic model of phloem transport which explains sink priority. J Exp Bot. 44:947-955.

Mitchell PJ, McAdam SAM, Pinkard EA, Brodribb TJ (2017) Significant contribution from foliage-derived ABA in regulating gas exchange in Pinus radiata. Tree Physiol. 37:236-245.

Mody K, Eichenberger D, Dorn S (2009) Stress magnitude matters: different intensities of pulsed water stress produce non-monotonic resistance responses of host plants to insect herbivores. Ecological Entomology. 34:133-143.

Mokany K, Raison RJ, Prokushkin AS (2006) Critical analysis of root : shoot ratios in terrestrial biomes. Glob Change Biol. 12:84-96.

Morandi B, Losciale P, Manfrini L, Zibordi M, Anconelli S, Galli F, Pierpaoli E, Grappadelli LC (2014) Increasing water stress negatively affects pear fruit growth by reducing first its xylem and then its phloem inflow. J Plant Physiol. 171:1500-1509.

Munns R, Cramer GR (1996) Is coordination of leaf and root growth mediated by abscisic acid? Opinion. Plant and Soil. 185:33-49. 
Netherer S, Matthews B, Katzensteiner K, Blackwell E, Henschke P, Hietz P, Pennerstorfer J, Rosner S, Kikuta $\mathrm{S}$, Schume $\mathrm{H}$, Schopf A (2015) Do water-limiting conditions predispose Norway spruce to bark beetle attack? New Phytol. 205:1128-1141.

Nguyen A, Lamant A (1988) Pinitol and myo-inositol accumulation in water-stressed seedlings of maritime pine. Phytochemistry. 27:3423-3427.

Nieminen K, Robischon M, Immanen J, Helariutta Y (2012) Towards optimizing wood development in bioenergy trees. New Phytol. 194:46-53.

Niinemets Ü (2016) Uncovering the hidden facets of drought stress: secondary metabolites make the difference. Tree Physiol. 36:129-132.

Nikinmaa E, Hölttä T, Hari P, Kolari P, Mäkelä A, Sevanto S, Vesala T (2013) Assimilate transport in phloem sets conditions for leaf gas exchange. Plant, Cell \& Environment. 36:655-669.

O'Brien MJ, Leuzinger S, Philipson CD, Tay J, Hector A (2014) Drought survival of tropical tree seedlings enhanced by non-structural carbohydrate levels. Nature Clim Change. 4:710-714.

Oparka KJ, Duckett CM, Prior DAM, Fisher DB (1994) Real-time imaging of phloem unloading in the root tip of Arabidopsis. The Plant Journal. 6:759-766.

Pantin F, Fanciullino A-L, Massonnet C, Dauzat M, Simonneau T, Muller B (2013) Buffering growth variations against water deficits through timely carbon usage. Front Plant Sci. 4

Payyavula RS, Tay KHC, Tsai CJ, Harding SA (2011) The sucrose transporter family in Populus: the importance of a tonoplast PtaSUT4 to biomass and carbon partitioning. The Plant Journal. 65:757770.

Pegoraro E, Rey A, Greenberg J, Harley P, Grace J, Malhi Y, Guenther A (2004) Effect of drought on isoprene emission rates from leaves of Quercus virginiana Mill. Atmospheric Environment. 38:6149-6156.

Pfautsch S, Hölttä T, Mencuccini M (2015) Hydraulic functioning of tree stems-fusing ray anatomy, radial transfer and capacitance. Tree Physiol. 35:706-722.

Pompon J, Quiring D, Goyer C, Giordanengo P, Pelletier Y (2011) A phloem-sap feeder mixes phloem and xylem sap to regulate osmotic potential. Journal of Insect Physiology. 57:1317-1322.

Poorter H, Niklas KJ, Reich PB, Oleksyn J, Poot P, Mommer L (2012) Biomass allocation to leaves, stems and roots: meta-analyses of interspecific variation and environmental control. New Phytol. 193:30-50.

Porth I, White R, Jaquish B, Ritland K (2018) Partial correlation analysis of transcriptomes helps detangle the growth and defense network in spruce. New Phytol. 218:1349-1359.

Pringle EG (2016) Integrating plant carbon dynamics with mutualism ecology. New Phytol. 210:71-75.

Prislan P, Gričar J, de Luis M, Smith KT, Čufar K (2013) Phenological variation in xylem and phloem formation in Fagus sylvatica from two contrasting sites. Agric For Meteorol. 180:142-151.

Pritchard J, Griffiths B, Hunt EJ (2007) Can the plant-mediated impacts on aphids of elevated $\mathrm{CO}_{2}$ and drought be predicted? Glob Change Biol. 13:1616-1629.

Raffa KF, Aukema BH, Erbilgin N, Klepzig KD, Wallin KF (2005) Interactions among conifer terpenoids and bark beetles across multiple levels of scale: An attempt to understand links between population patterns and physiological processes. Recent Advances in Phytochemistry. 39:80-118.

Reichstein M, Bahn M, Ciais P, Frank D, Mahecha MD, Seneviratne SI, Zscheischler J, Beer C, Buchmann N, Frank DC, Papale D, Rammig A, Smith P, Thonicke K, van der Velde M, Vicca S, Walz A, Wattenbach M (2013) Climate extremes and the carbon cycle. Nature. 500:287.

Reid CPP (1974) Assimilation, distribution, and root exudation of ${ }^{14} \mathrm{C}$ by Ponderosa pine seedlings under induced water stress. Plant Physiology. 54:44-49.

Reid CPP, Mexal JG (1977) Water stress effects on root exudation by Lodgepole pine. Soil Biology and Biochemistry. 9:417-421.

Rennie EA, Turgeon R (2009) A comprehensive picture of phloem loading strategies. Proceedings of the National Academy of Sciences. 106:14162-14167.

Risk D, Nickerson N, Phillips CL, Kellman L, Moroni M (2012) Drought alters respired $\delta^{13} \mathrm{CO}_{2}$ from autotrophic, but not heterotrophic soil respiration. Soil Biology and Biochemistry. 50:26-32.

Rowland L, da Costa ACL, Galbraith DR, Oliveira RS, Binks OJ, Oliveira AAR, Pullen AM, Doughty CE, Metcalfe DB, Vasconcelos SS, Ferreira LV, Malhi Y, Grace J, Mencuccini M, Meir P (2015) Death from drought in tropical forests is triggered by hydraulics not carbon starvation. Nature. 528:119-122. 
Ruehr NK, Offermann CA, Gessler A, Winkler JB, Ferrio JP, Buchmann N, Barnard RL (2009) Drought effects on allocation of recent carbon: from beech leaves to soil $\mathrm{CO}_{2}$ efflux. New Phytol. 184:950-961.

Ryan MG, Asao S (2014) Phloem transport in trees. Tree Physiol. 34:1-4.

Ryan MG, Sapes G, Sala A, Hood SM (2015) Tree physiology and bark beetles. New Phytol. 205:955-957.

Sala A, Piper F, Hoch G (2010) Physiological mechanisms of drought-induced tree mortality are far from being resolved. New Phytol. 186:274-281.

Salmon Y, Li X, Yang B, Ma K, Siegwolf RTW, Schmid B (2018) Surrounding species diversity improves subtropical seedlings' carbon dynamics. Ecol Evol. 8:7055-7067.

Salmon Y, Torres-Ruiz JM, Poyatos R, Martinez-Vilalta J, Meir P, Cochard H, Mencuccini M (2015) Balancing the risks of hydraulic failure and carbon starvation: a twig scale analysis in declining Scots pine. Plant, Cell \& Environment. 38:2575-2588.

Savage JA, Beecher SD, Clerx L, Gersony JT, Knoblauch J, Losada JM, Jensen KH, Knoblauch M, Holbrook NM (2017) Maintenance of carbohydrate transport in tall trees. Nat Plants. 3:965-972.

Savage JA, Clearwater MJ, Haines DF, Klein T, Mencuccini M, Sevanto S, Turgeon R, Zhang C (2016) Allocation, stress tolerance and carbon transport in plants: how does phloem physiology affect plant ecology? Plant, Cell \& Environment. 39:709-725.

Schopfer P (2006) Biomechanics of plant growth. American Journal of Botany. 93:1415-1425.

Schuetz M, Smith R, Ellis B (2013) Xylem tissue specification, patterning, and differentiation mechanisms. J Exp Bot. 64:11-31.

Schultz JC, Appel HM, Ferrieri AP, Arnold TM (2013) Flexible resource allocation during plant defense responses. Front Plant Sci. 4

Serraj R, Sinclair TR, Purcell LC (1999) Symbiotic $N_{2}$ fixation response to drought. J Exp Bot. 50:143-155.

Sevanto S (2014) Phloem transport and drought. J Exp Bot. 65:1751-1759.

Sevanto S (2018) Drought impacts on phloem transport. Current Opinion in Plant Biology. 43:76-81.

Sevanto S, Hölttä T, Holbrook NM (2011) Effects of the hydraulic coupling between xylem and phloem on diurnal phloem diameter variation. Plant, Cell \& Environment. 34:690-703.

Sevanto S, McDowell NG, Dickman LT, Pangle R, Pockman WT (2014) How do trees die? A test of the hydraulic failure and carbon starvation hypotheses. Plant, Cell \& Environment. 37:153-161.

Sevanto S, Ryan M, Dickman LT, Derome D, Patera A, Defraeye T, Pangle RE, Hudson PJ, Pockman WT (2018) Is desiccation tolerance and avoidance reflected in xylem and phloem anatomy of two coexisting arid-zone coniferous trees? Plant, Cell \& Environment. 41:\{Windt, 2006 \#18\}\{Knoblauch, 2014 \#15\}1551-1654.

Sharkey TD, Wiberley AE, Donohue AR (2008) Isoprene emission from plants: Why and how. Annals of Botany. 101:5-18.

Six DL, Poulsen M, Hansen AK, Wingfield MJ, Roux J, Eggleton P, Slippers B, Paine TD (2011) Anthropogenic effects on interaction outcomes: examples from insect-microbial symbioses in forest and savanna ecosystems. Symbiosis. 53:101-121.

Skomarkova MV, Vaganov EA, Mund M, Knohl A, Linke P, Boerner A, Schulze ED (2006) Inter-annual and seasonal variability of radial growth, wood density and carbon isotope ratios in tree rings of beech (Fagus sylvatica) growing in Germany and Italy. Trees-Struct Funct. 20:571-586.

Slovik S, Daeter W, Hartung W (1995) Compartmental redistribution and long-distance transport of abscisic acid $(A B A)$ in plants as influenced by environmental changes in the rhizosphere $-a$ biomathematical model. J Exp Bot. 46:881-894.

Smith JAC, Milburn JA (1980) Phloem turgor and the regulation of sucrose loading in Ricinus communis L. Planta. 148:42-48.

Sorce C, Giovannelli A, Sebastiani L, Anfodillo T (2013) Hormonal signals involved in the regulation of cambial activity, xylogenesis and vessel patterning in trees. Plant Cell Reports. 32:885-898.

Sovonick-Dunford S, Ferrier JM, Dainty J (1983) Water-relations parameters of the phloem. Determinations of volumetric elastic modulus and membrane conductivity using an applied force method and shrinkage and swelling of tissues in solutions at differing osmotic pressure. Annals of Botany. 51:2737. 
Stanfield RC, Hacke UG, Laur J (2017) Are phloem sieve tubes leaky conduits supported by numerous aquaporins? American Journal of Botany. 104:719-732.

Steele CL, Lewinsohn E, Croteau R (1995) Induced oleoresin biosynthesis in grand fir as a defense against bark beetles. Proceedings of the National Academy of Sciences. 92:4164-4168.

Stoy PC, Palmroth S, Oishi AC, Siqueira MB, Juang JY, Novick KA, Ward EJ, Katul GG, Oren R (2007) Are ecosystem carbon inputs and outputs coupled at short time scales? A case study from adjacent pine and hardwood forests using impulse-response analysis. Plant Cell Environ. 30:700-10.

Swidrak I, Gruber A, Oberhuber W (2014) Xylem and phloem phenology in co-occurring conifers exposed to drought. Trees-Struct Funct. 28:1161-1171.

Thompson MV, Holbrook NM (2003) Application of a single-solute non-steady-state phloem model to the study of long-distance assimilate transport. Journal of Theoretical Biology. 220:419-455.

Thompson MV, Zwieniecki MA (2005) The Role of Potassium in Long Distance Transport in Plants Vascular Transport in Plants. Academic Press, Burlington, pp 221-240.

Torode TA, O'Neill R, Marcus SE, Cornuault V, Pose S, Lauder RP, Kračun SK, Rydahl MG, Andersen MCF, Willats WGT, Braybrook SA, Townsend BJ, Clausen MH, Knox JP (2018) Branched pectic galactan in phloem-sieve-element cell walls: Implications for cell mechanics. Plant Physiology. 176:1547-1558.

Turgeon R (2010) The Role of Phloem Loading Reconsidered. Plant Physiology. 152:1817-1823.

Turgeon R, Wolf S (2009) Phloem transport: Cellular pathways and molecular trafficking. Annual Review of Plant Biology. 60:207-221.

Tyree MT, Christy AL, Ferrier JM (1974) A simpler iterative steady state solution of Münch pressure-flow systems applied to long and short translocation paths. Plant Physiology. 54:589-600.

Wallin KF, Raffa KF (2001) Effects of folivory on subcortical plant defenses: can defense theories predict interguild processes? Ecology. 82:1387-1400.

Van Bel AJE (1992) Different phloemloading machineries correlated with the climate. Acta Botanica Neerlandica 42:121-141.

Van Bel AJE (2003) The phloem, a miracle of ingenuity. Plant, Cell \& Environment. 26:125-149.

van Bel AJE, Gamalei YV (1992) Ecophysiology of phloem loading in sources leaves. Plant Cell Environ. 15:265-270.

Waring RH, Pitman GB (1985) Modifying lodgepole pine stands to change susceptibility to mountain pine beetle attack. Ecology. 66:889-897.

Wermelinger B, Rigling A, Schneider MD, Dobbertin M (2008) Assessing the role of bark- and wood-boring insects in the decline of Scots pine (Pinus sylvestris) in the Swiss Rhone valley. Ecological Entomology. 33:239-249.

White TCR (1969) An index to measure weather-induced stress of trees associated with outbreaks of psyllids in Australia. Ecology. 50:905-909.

White TCR (2015) Are outbreaks of cambium-feeding beetles generated by nutritionally enhanced phloem of drought-stressed trees? J Appl Entomol. 139:567-578.

Whyte G, Howard K, Hardy GESJ, Burgess TI (2016) The tree decline recovery seesaw; a conceptual model of the decline and recovery of drought stressed plantation trees. Forest Ecology and Management. 370:102-113.

Wiley E, Helliker B (2012) A re-evaluation of carbon storage in trees lends greater support for carbon limitation to growth. New Phytol. 195:285-289.

Will T, Furch ACU, Zimmermann MR (2013) How phloem-feeding insects face the challenge of phloemlocated defenses. Front Plant Sci. 4

Will T, Kornemann SR, Furch ACU, Tjallingii WF, van Bel AJE (2009) Aphid watery saliva counteracts sievetube occlusion: a universal phenomenon? Journal of Experimental Biology. 212:3305-3312.

Windt CW, Vergeldt FJ, De Jager PA, Van As H (2006) MRI of long-distance water transport: a comparison of the phloem and xylem flow characteristics and dynamics in poplar, castor bean, tomato and tobacco. Plant, Cell \& Environment. 29:1715-1729.

Wood DL (1982) The role of pheromones, kairomones, and allomones in the host selection and colonization behavior of bark beetles. Annual Review of Entomology. 27:411-446. 
Woodruff DR (2014) The impacts of water stress on phloem transport in Douglas-fir trees. Tree Physiol. 34:5-14.

Wright JP, Fisher DB (1983) Estimation of the volumetric elastic modulus and membrane hydraulic conductivity of willow sieve tubes. Plant Physiology. 73:1042-1047.

Xiloyannis C, Dichio B, Nuzzo V, Celano G. 1999. Defence strategies of olive against water stress. International Society for Horticultural Science (ISHS), Leuven, Belgium, pp 423-426.

Xu QY, Chen SY, Ren YJ, Chen SL, Liesche J (2018) Regulation of sucrose transporters and phloem loading in response to environmental cues. Plant Physiology. 176:930-945.

Zang U, Goisser M, Grams TEE, Häberle K-H, Matyssek R, Matzner E, Borken W (2014) Fate of recently fixed carbon in European beech (Fagus sylvatica) saplings during drought and subsequent recovery. Tree Physiol. 34:29-38.

Zhao MS, Running SW (2010) Drought-induced reduction in global terrestrial net primary production from 2000 through 2009. Science. 329:940-943.

\section{Legends}

Figure 1: A schematic illustration of phloem transport of carbohydrates based on the Münch pressure - flow hypothesis and its response to drought. Phloem loading $(\mathrm{L})$ and unloading $(\mathrm{U})$ create a pressure gradient $(\Delta \mathrm{P})$ driving the mass flow of carbohydrates $(\mathrm{F})$. The flow rate also depends on the fluid viscosity $(\eta)$ and conduit radius $(r)$. Phloem and xylem exchange water either at source and sink areas only or along the entire path if the cell walls of the sieve elements are semi permeable (dotted white arrows). Dotted black arrows indicate a putative local loading and unloading of solutes along transport phloem (leaky phloem).

Figure 2: Simplified conceptual model (left) of the effects of drought (driven by the decrease in water potential) on several physiological processes in the foliage of an anisohydric species (top), in roots (bottom) and along the phloem path (middle), and hypothetic physiological changes during drought progression (right; areas in light, medium and dark grey depict mild, moderate and severe drought). Top panels: leaf photosynthesis is less sensitive than leaf growth and starts to decrease under moderate drought; photosynthesis is almost zero under severe drought conditions (it would start to decrease under mild drought for an isohydric species). Leaf respiration also decreases but it is less sensitive than photosynthesis. The amount of $\mathrm{C}$ immobilized for osmoregulation or defence, or lost as volatile organic compounds (VOC) is expected to increase during the progression of drought, at least until drought is severe enough. The amount of carbohydrate available for export is thus decreasing with increasing drought intensity. Bottom panels: root growth is less sensitive than leaf growth, maintaining sink strength under mild drought conditions. C requirement for osmoregulation, defence and enhance exudation also contribute to sink strength, at least until drought is severe enough. An active storage under drought remains speculative. Middle panels: phloem loading and unloading remain largely unaffected by mild drought, decrease under moderate drought due to both a decrease in the amount of $\mathrm{C}$ available for export in source and a decrease in carbohydrate requirement in sinks, and almost cease during severe drought. Whereas change in $\mathrm{C}$ translocation is mainly related to change in source activity (phloem loading) and sink activity (phloem unloading), a marked increase in sap viscosity or collapse of turgor in sieve elements cannot be excluded under severe drought conditions. Allocation of $\mathrm{C}$ to inducible defences might be impaired while constitutive defences might be enhanced under drought. In the graphs, well-established responses are depicted with full lines whereas more speculative responses are depicted with dotted lines. The schematic model is simplistic in the sense that it does not take into account all existing physiological processes, links between water, carbon and nutrient fluxes, and possible feedbacks. Signs (+ or -$)$ are associated to each arrow (individual effect). The overall effect of drought is the product of these individual effects. For 
1140 example: low water potential has a negative effect on photosynthesis (-), photosynthesis has a positive

1141 effect on available $\mathrm{C}$ in source $(+)$ so low water potential has a negative effect on available $\mathrm{C}$ in source $1142(+\times-=-)$. 


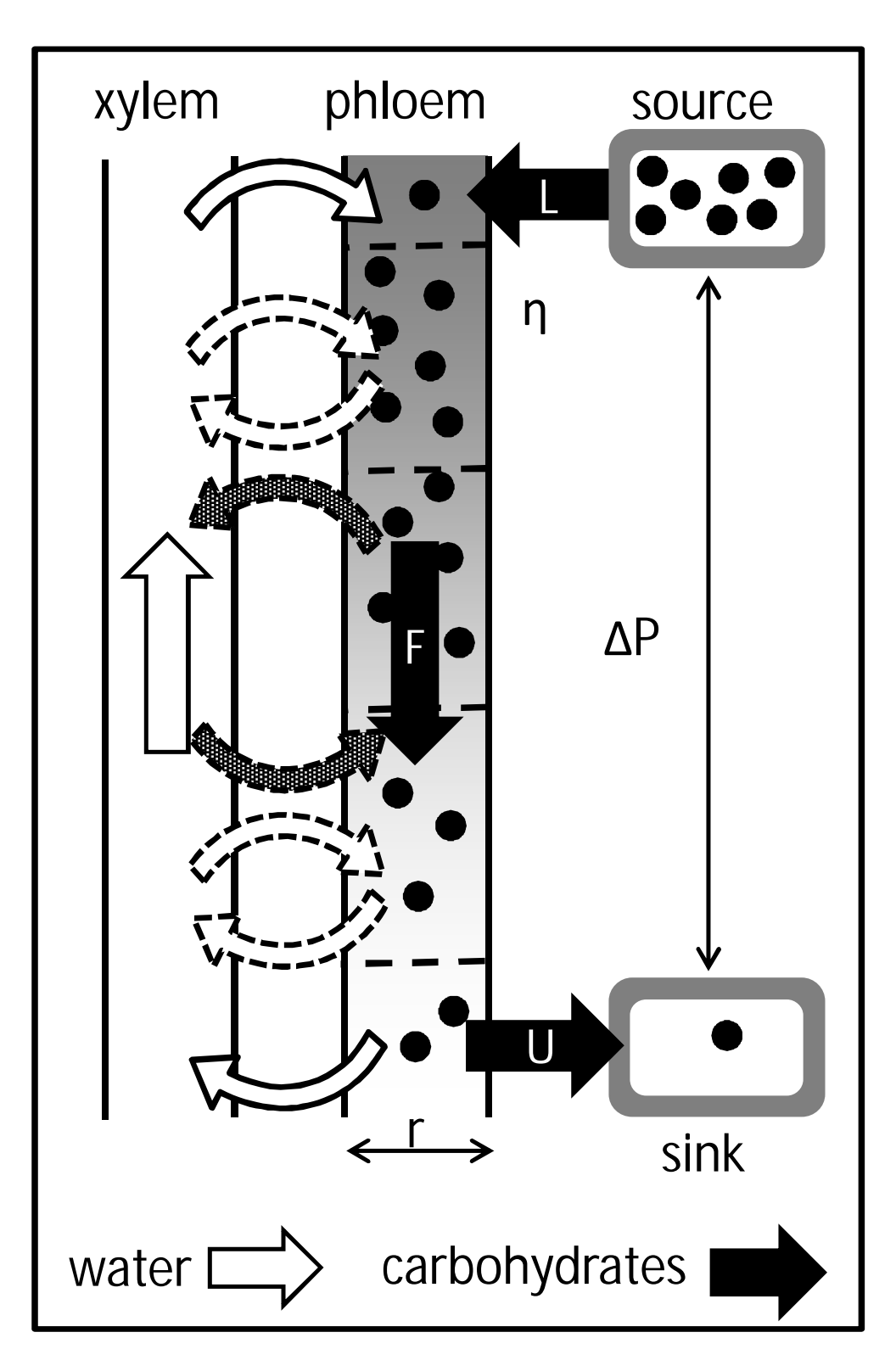




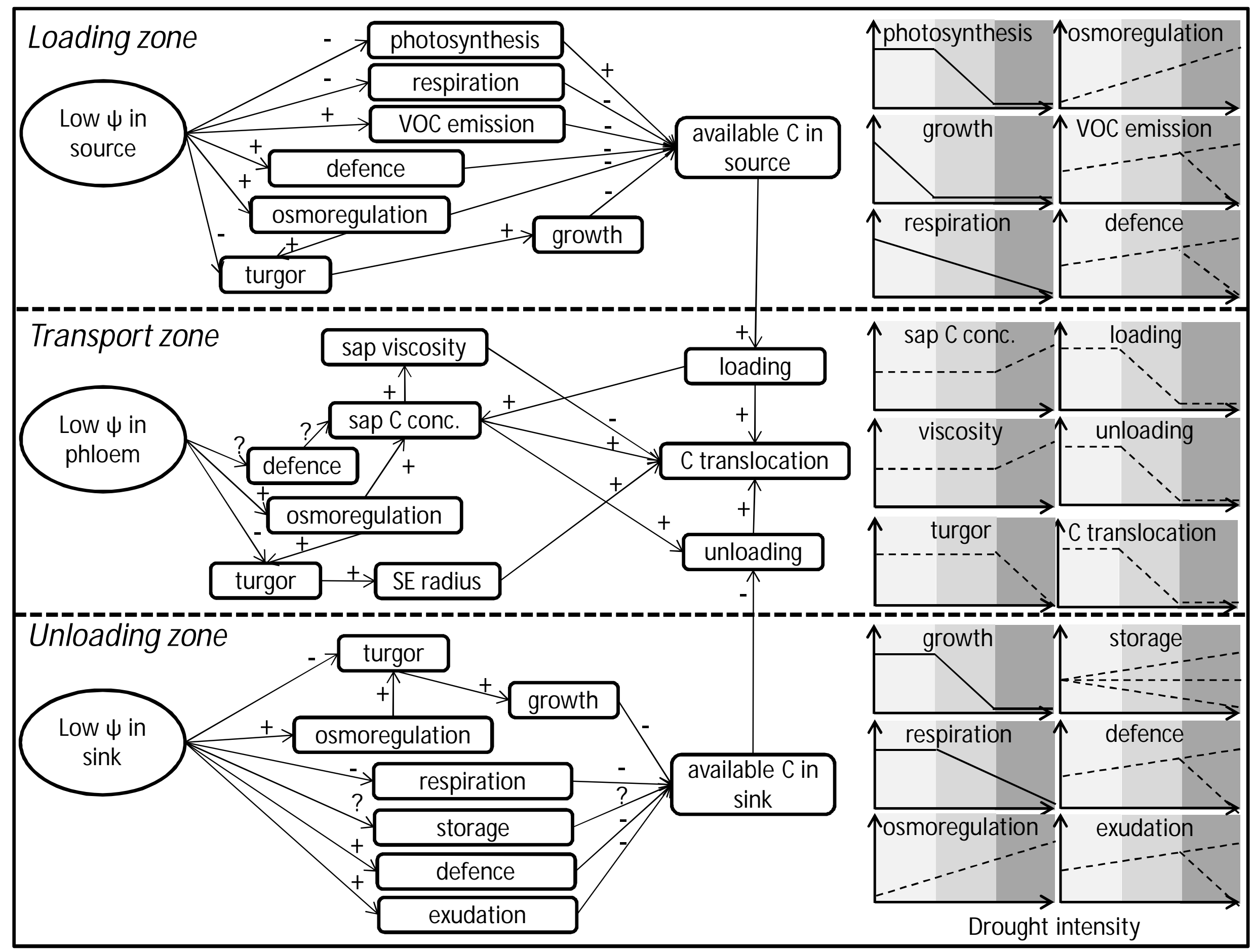


Table 1: Summary of experimental studies investigating the effect of drought on phloem functions and properties (L: phloem loading, Tr: phloem transport, C: phloem sap composition, Tu: turgor, A: anatomy)

\begin{tabular}{|c|c|c|c|c|c|c|c|}
\hline Species & Stage & Conditions & Drought & Intensity $^{\mathrm{a}}$ & Methods & Main results & Reference \\
\hline Salix vinunalis & $\begin{array}{l}\text { young potted } \\
\text { trees }\end{array}$ & laboratory & osmotic stress & moderate & exudate collection & $\begin{array}{l}\text { Tr: lower exudation rate } \\
\text { C: higher solute content }\end{array}$ & $\begin{array}{l}\text { (Weatherley et al. } \\
\text { 1959) }\end{array}$ \\
\hline $\begin{array}{l}\text { Ricinus } \\
\text { communis }\end{array}$ & $\begin{array}{l}\text { seedlings (6- } \\
\text { wk-old) }\end{array}$ & laboratory & $\begin{array}{l}\text { water removal, } \\
\text { leaf excision }\end{array}$ & $\begin{array}{l}\text { moderate to } \\
\text { severe }\end{array}$ & $\begin{array}{l}{ }^{14} \mathrm{C} \text { labelling, } \\
\text { exudate collection }\end{array}$ & $\begin{array}{l}\text { Tr: lower exudation rate } \\
\text { C: slightly higher solute } \\
\text { content }\end{array}$ & $\begin{array}{l}\text { (Hall and Milburn } \\
\text { 1973) }\end{array}$ \\
\hline $\begin{array}{l}\text { Gossypium } \\
\text { hirsutum }\end{array}$ & seedlings & $\begin{array}{l}\text { greenhouse } \\
\text { and field }\end{array}$ & $\begin{array}{l}\text { controlled } \\
\text { watering }\end{array}$ & $\begin{array}{l}\text { mild to } \\
\text { severe }\end{array}$ & ${ }^{14} \mathrm{C}$ labelling & $\begin{array}{l}\text { Tr: lower exudation rate } \\
\text { but less sensitive than } \\
\mathrm{CO}_{2} \text { assimilation }\end{array}$ & $\begin{array}{l}\text { (Sung and Krieg } \\
1979 \text { ) }\end{array}$ \\
\hline $\begin{array}{l}\text { Ricinus } \\
\text { communis }\end{array}$ & $\begin{array}{l}\text { seedlings }(9- \\
\text { wk-old) }\end{array}$ & laboratory & $\begin{array}{l}\text { root excision, } \\
\text { osmotic stress }\end{array}$ & $\begin{array}{l}\text { mild to } \\
\text { severe }\end{array}$ & $\begin{array}{l}\text { exudate } \\
\text { collection, } \\
{ }^{14} \mathrm{C} \text { sugar uptake }\end{array}$ & $\begin{array}{l}\text { L: Higher rate of sugar } \\
\text { uptake by leaf discs } \\
\text { Tr: lower exudation rate } \\
\text { C: higher solute content } \\
\text { Tu: maintained }\end{array}$ & $\begin{array}{l}\text { (Smith and } \\
\text { Milburn 1980) }\end{array}$ \\
\hline $\begin{array}{l}\text { Theobroma } \\
\text { cacao }\end{array}$ & $\begin{array}{l}\text { seedlings (14- } \\
\text { wk-old) }\end{array}$ & greenhouse & $\begin{array}{l}\text { controlled } \\
\text { watering }\end{array}$ & $\begin{array}{l}\text { mild to } \\
\text { moderate }\end{array}$ & ${ }^{14} \mathrm{C}$ labelling & $\begin{array}{l}\text { L: longer residence time ( } \\
\text { moderate drought) } \\
\text { Tr: increased difference in } \\
\text { time lags }\end{array}$ & $\begin{array}{l}\text { (Deng et al. 1990a; } \\
\text { Deng et al. 1990b) }\end{array}$ \\
\hline $\begin{array}{l}\text { Fagus } \\
\text { sylvatica }\end{array}$ & $\begin{array}{l}\text { seedlings }(1.5- \\
\text { yr-old) }\end{array}$ & greenhouse & $\begin{array}{l}\text { controlled } \\
\text { watering }\end{array}$ & moderate & ${ }^{13} \mathrm{C}$ labelling & $\begin{array}{l}\text { L: longer residence time } \\
\text { Tr: increased difference in } \\
\text { time lags }\end{array}$ & (Ruehr et al. 2009) \\
\hline $\begin{array}{l}\text { Fagus } \\
\text { sylvatica }\end{array}$ & $\begin{array}{l}\text { potted } \\
\text { saplings }(0.8- \\
\text { m-tall })\end{array}$ & $\begin{array}{l}\text { climate } \\
\text { chamber }\end{array}$ & $\begin{array}{l}\text { controlled } \\
\text { watering }\end{array}$ & moderate & ${ }^{13} \mathrm{C}$ labelling & $\begin{array}{l}\text { Tr: increased difference in } \\
\text { time lags }\end{array}$ & $\begin{array}{l}\text { (Barthel et al. } \\
\text { 2011) }\end{array}$ \\
\hline $\begin{array}{l}\text { Fagus } \\
\text { sylvatica }\end{array}$ & $\begin{array}{l}\text { trees }(20-y r- \\
\text { old) }\end{array}$ & forest & rain exclusion & mild & ${ }^{13} \mathrm{C}$ labelling & Tr: no effect & $\begin{array}{l}\text { (Dannoura et al. } \\
\text { 2011) }\end{array}$ \\
\hline $\begin{array}{l}\text { Quercus } \\
\text { petraea }\end{array}$ & $\begin{array}{l}\text { trees }(20-y r- \\
\text { old })\end{array}$ & forest & summer drought & mild & ${ }^{13} \mathrm{C}$ labelling & $\begin{array}{l}\text { Tr: increased difference in } \\
\text { time lags }\end{array}$ & (Dannoura et al. \\
\hline Pinus pinaster & $\begin{array}{l}\text { trees }(12-y r- \\
\text { old) }\end{array}$ & plantation & $\begin{array}{l}\text { rain exclusion } \\
\text { after summer } \\
\text { drought }\end{array}$ & mild & ${ }^{13} \mathrm{C}$ labelling & $\begin{array}{l}\text { Tr: increased difference in } \\
\text { time lags }\end{array}$ & $\begin{array}{l}\text { (Dannoura et al. } \\
\text { 2011) }\end{array}$ \\
\hline
\end{tabular}




\begin{tabular}{|c|c|c|c|c|c|c|c|}
\hline Pinus edulis & $\begin{array}{l}\text { potted mature } \\
\text { trees }(2-\mathrm{m}- \\
\text { tall) }\end{array}$ & greenhouse & zero irrigation & severe & $\begin{array}{l}\text { linear } \\
\text { displacement } \\
\text { transducers }\end{array}$ & $\begin{array}{l}\text { C: lower sucrose content } \\
\text { Tu: collapse preceded } \\
\text { mortality }\end{array}$ & $\begin{array}{l}\text { (Sevanto et al. } \\
\text { 2014) }\end{array}$ \\
\hline $\begin{array}{l}\text { Pseudotsuga } \\
\text { menziesii }\end{array}$ & $\begin{array}{l}\text { trees }(2 \text { to } 60- \\
\text { m-tall) }\end{array}$ & forest & $\begin{array}{l}\text { tree height } \\
\text { gradient }\end{array}$ & moderate & & $\begin{array}{l}\mathrm{C}: \text { higher sugar content } \\
\text { A: smaller sieve element } \\
\text { radius }\end{array}$ & (Woodruff 2014) \\
\hline $\begin{array}{l}\text { Fagus } \\
\text { sylvatica }\end{array}$ & $\begin{array}{l}\text { potted } \\
\text { saplings }(5-\mathrm{yr}- \\
\text { old) }\end{array}$ & $\begin{array}{l}\text { forest, climate } \\
\text { chamber }\end{array}$ & rain exclusion & moderate & ${ }^{13} \mathrm{C}$ labelling & $\begin{array}{l}\text { L: longer residence time } \\
\text { Tr: increased difference in } \\
\text { time lags }\end{array}$ & (Zang et al. 2014) \\
\hline $\begin{array}{l}\text { Fagus } \\
\text { sylvatica }\end{array}$ & $\begin{array}{l}\text { potted } \\
\text { saplings (1-m- } \\
\text { tall) }\end{array}$ & $\begin{array}{l}\text { climate } \\
\text { chamber }\end{array}$ & $\begin{array}{l}\text { controlled } \\
\text { watering }\end{array}$ & mild & ${ }^{13} \mathrm{C}$ labelling & $\begin{array}{l}\text { L: slightly longer } \\
\text { residence time } \\
\text { Tr: no effect on time lags }\end{array}$ & $\begin{array}{l}\text { (Blessing et al. } \\
\text { 2015) }\end{array}$ \\
\hline $\begin{array}{l}\text { Eucalyptus } \\
\text { grandis }\end{array}$ & $\begin{array}{l}\text { trees }(9 \text { to } 12- \\
\text { m-tall) }\end{array}$ & plantation & rain exclusion & mild & ${ }^{13} \mathrm{C}$ labelling & $\begin{array}{l}\text { L: no effect on residence } \\
\text { time } \\
\text { Tr: no effect on time lags }\end{array}$ & (Epron et al. 2016) \\
\hline $\begin{array}{l}\text { Fagus } \\
\text { sylvatica }\end{array}$ & $\begin{array}{l}\text { seedlings }(2- \\
\text { yr-old) }\end{array}$ & greenhouse & $\begin{array}{l}\text { controlled } \\
\text { watering }\end{array}$ & mild & ${ }^{13} \mathrm{C}$ labelling & Tr: no effect on time lags & $\begin{array}{l}\text { (Hommel et al. } \\
\text { 2016) }\end{array}$ \\
\hline $\begin{array}{l}\text { Acer } \\
\text { platanoides }\end{array}$ & $\begin{array}{l}\text { seedlings (2- } \\
\text { yr-old) }\end{array}$ & greenhouse & $\begin{array}{l}\text { controlled } \\
\text { watering }\end{array}$ & mild & ${ }^{13} \mathrm{C}$ labelling & Tr: no effect on time lags & $\begin{array}{l}\text { (Hommel et al. } \\
\text { 2016) }\end{array}$ \\
\hline $\begin{array}{l}\text { Fagus } \\
\text { sylvatica }\end{array}$ & $\begin{array}{l}\text { young trees } \\
(8-\mathrm{yr}-\mathrm{old})\end{array}$ & tree nursery & rain exclusion & $\begin{array}{l}\text { moderate to } \\
\text { severe }\end{array}$ & ${ }^{13} \mathrm{C}$ labelling & $\begin{array}{l}\text { L: longer residence time } \\
\text { Tr: increased difference in } \\
\text { time lags } \\
\text { C: higher sugar content } \\
\text { A: smaller sieve element } \\
\text { radius }\end{array}$ & $\begin{array}{l}\text { (Dannoura et al. } \\
\text { 2019) }\end{array}$ \\
\hline $\begin{array}{l}\text { Populus } \\
\text { tremula }\end{array}$ & potted & $\begin{array}{l}\text { greenhouse, } \\
\text { laboratory }\end{array}$ & $\begin{array}{l}\text { controlled } \\
\text { watering }\end{array}$ & $\begin{array}{l}\text { moderate to } \\
\text { severe }\end{array}$ & $\begin{array}{l}{ }^{11} \mathrm{C} \text { labelling, } \\
\text { PET imaging }\end{array}$ & $\begin{array}{l}\text { Tr: reduction in phloem } \\
\text { sap velocity in leaves }\end{array}$ & $\begin{array}{l}\text { Hubeau et al } \\
(2019)\end{array}$ \\
\hline
\end{tabular}

${ }^{a}$ Mild: net $\mathrm{CO}_{2}$ assimilation above $50 \%$ of control; moderate: net $\mathrm{CO}_{2}$ assimilation below $50 \%$ of control, and no turgor loss; severe: net $\mathrm{CO}_{2}$ assimilation at zero, turgor loss, just before death. 
Table 2: Expected effects of drought on several characteristic of the phloem and putative consequences on sap feeder and cambium feeder pests

\begin{tabular}{lccc}
\cline { 2 - 3 } & $\begin{array}{c}\text { Drought } \\
\text { response }\end{array}$ & Sap feeders & Cambium feeders \\
\hline Constitutive defence & + & - & - \\
Inducible defence & - & + & + \\
ABA in phloem sap & + & - & $=$ \\
Turgor & - & - & + \\
Osmotic adjustment and sap viscosity & + & - & + \\
Sap organic N & + & + & + \\
\hline Overall effects of drought & & - & + \\
\hline
\end{tabular}

